SINAI Journal of Applied Sciences 10 (2) $2021 \quad 205-218$

\begin{tabular}{lll}
\multicolumn{3}{c}{ Available online at www.sinjas.journals.ekb.eg } \\
SCREENED BY SINAI Journal of Applied Sciences
\end{tabular}

\title{
AN ECONOMIC STUDY FOR THE PRODUCTION OF DATE PALM CROP IN NORTH SINAI GOVERNORATE
}

\author{
Hosam El-Din Y. Tafily ${ }^{1 *}$, Soad A. Ibrahim ${ }^{1}$, R.M. Hefny ${ }^{1}$ \\ 1. Dept. Econ. and Rural Develop., Fac. Environ. Agric. Sci., Arish Univ., Egypt.
}

\section{ARTICLE INFO}

Article history:

Received: $10 / 07 / 2021$

Revised: 20/09/2021

Accepted: 11/10/2021

Available online: 11/10/2021

Keywords:

Date Palm,

costs,

production,

North Sinai Governorate

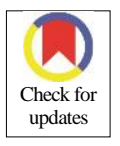

\begin{abstract}
Date palm trees and their identical products are considered as a by-product of the most important cultivations in the new and desert areas, as the palm products represent economic and environmental benefits. Study relied on the methods of descriptive and quantitative economic analysis, and in achieving its objectives; the research relied on both primary data and secondary data. The functions of the production of the date palm crop for the most important factors of production, which are the hours of human work, organic fertilizers and the number of fungicides. Average fixed costs amounted to about L.E. 2285 per feddan, representing about $24.84 \%$ of the total costs. Average variable costs amounted to about L.E. 6913.3 per feddan, which represents about $75.16 \%$ of the total costs, which amounted to about L.E. 9198.3 per feddan. The statistical measurement of the functions of costs of date palm crop in the short and long term was studied in the various tenure categories in the sample. The general average of net return was about 8.40 thousand found, average return on variable costs amounted to about L.E. 10.69 thousand, and the average value added amounted to about L.E. 12.78 thousand, and average return on costs was about 1.91 . The average return on the L.E. invested was about $91.3 \%$, and average product profit margin was about $47.7 \%$. Average economic efficiency was about 1.39 . Research recommends the necessity of increasing the farm area of date palm while preserving it from insects (Data palm) and making optimal use of the productive quantities when marketing.
\end{abstract}

بنظيرتها فى بعض المحافظات الأخرى. وعلى الرغم من

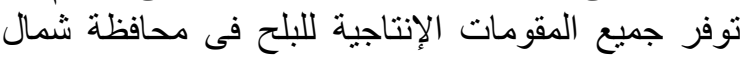

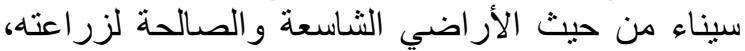

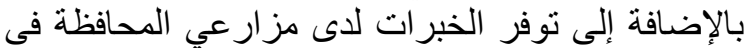

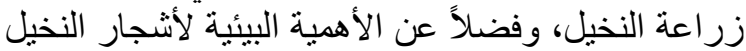

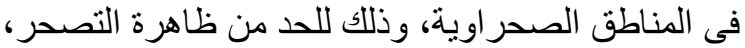

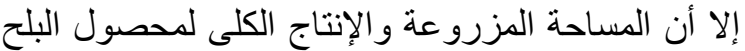

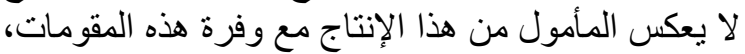

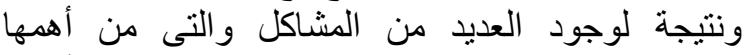

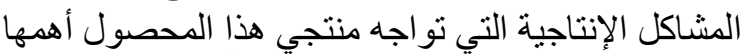

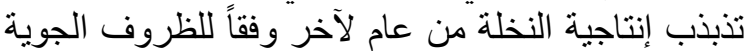

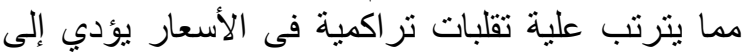

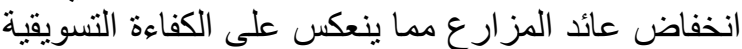

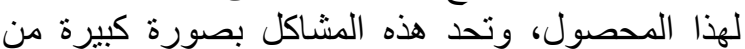

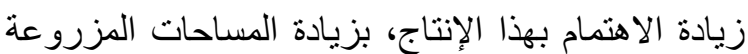

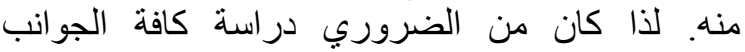
الإنتاجية المتعلقة بهذا المحصول، ومدى تحقيق الكفاءة

\section{مقدمة}

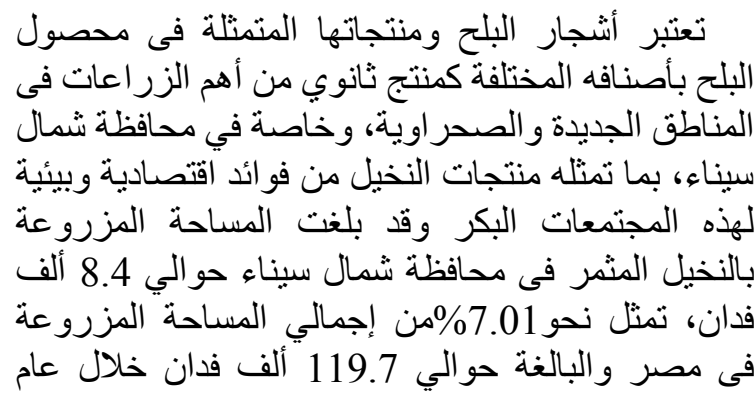
2017

\section{مُشكلة البحث}

علي الرغم من وجود عدداً كبيراً من أشجار النخيل

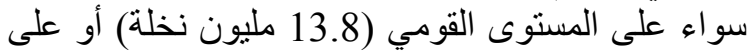

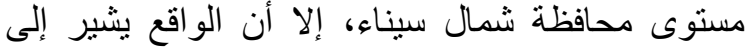
انخفاض انتاجية أثجار النخيل بالمحافظة، مقارنة

\footnotetext{
* Corresponding author: E-mail address: salemhossam827@gmail.com https://doi.org/10.21608/sinjas.2021.85163.1031

(c) 2021 SINAI Journal of Applied Sciences. Published by Fac. Environ. Agric. Sci., Arish Univ. All rights reserved.
} 
الإدارات الزراعية بالمراكز الإدارية التي تناولتها عينة

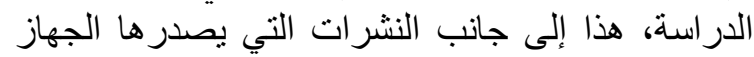

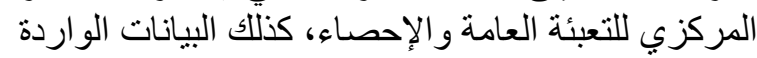

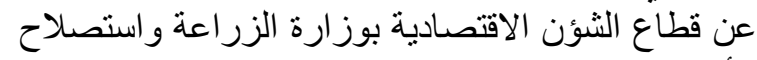
الأر اضي.

\section{التتائج ومناقشتها \\ اختيار عينة الدراسة في محافظة شمال سيناء \\ اختيار أهم مراكز العينة بمحافظة شمال سيناء}

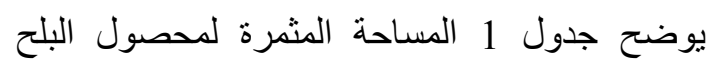
و عدد الحائزين ومتوسط نصيب الحائز، و الوسط الهندسي لوني

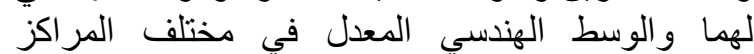
الإدارية بمحافظة شمال سيناء خلال منوسط الفي الفترة

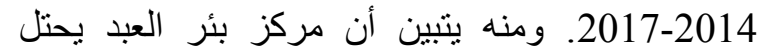

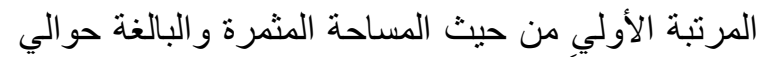

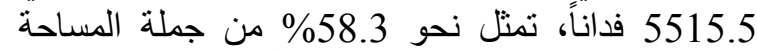

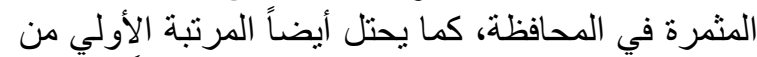

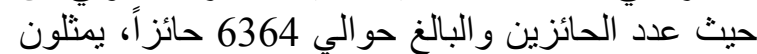

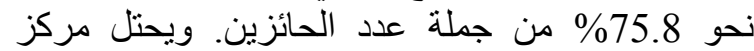
العريش المرتبة الثانية من حيث المساحة المثمرة والبالئة حو الي 2208 فداناً، تمثل نحو 23.4 \% من من جملة المساحة

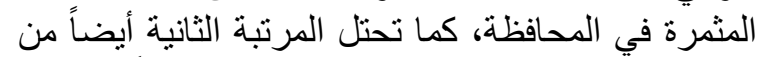

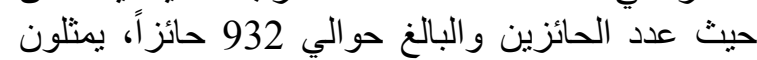
نحو 11.1\% من جملة عدد الحائزين. ويحتل مركز الثيخ زويد المرتبة الثالثة من حيث الثئ المساحة المثمرة

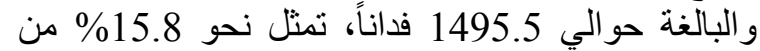
جملة المساحة المثمرة في المحافظة، كما تحتل المرتبة

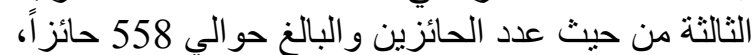
يمثلون نحو 6.8\% من جملة عدة عدد الحائزين. أما مركز حائز

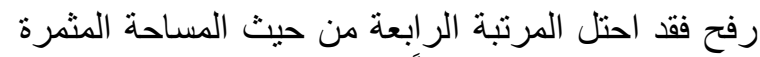

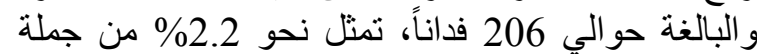

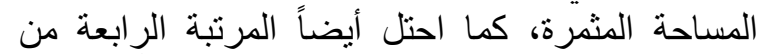

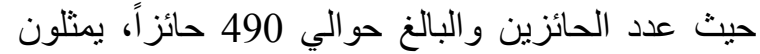
نحو 5.8\% من جملة عدد الحائزين. ويحتل مركزي الحئ نخل والحسنة المرتبتين الاخيرتين من حيث المبنة المساحة المثمرة،

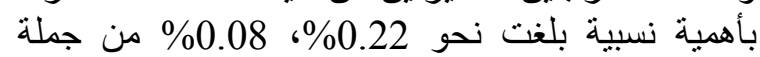
المساحة المثمرة في المحافظة والبالغة بلغة حوالي 9453.5

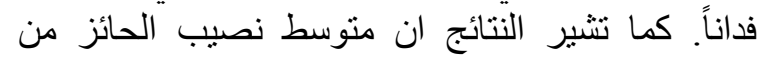

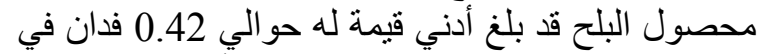

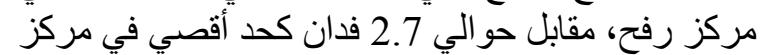

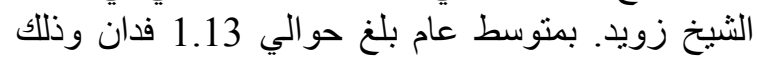

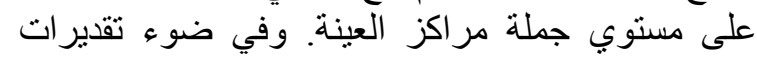

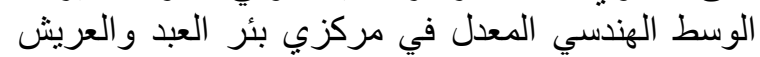

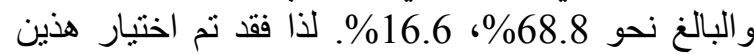

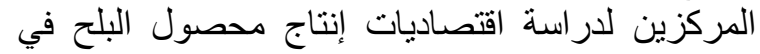

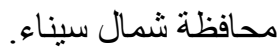

الإنتاجية، وأهم المعوقات التي تحول دون تحقيقها في

المحافظة (حسن،2011).

أهداف البحث

استهدف البحث بصفة عامة تحليل الكفاءة الإنتاجية

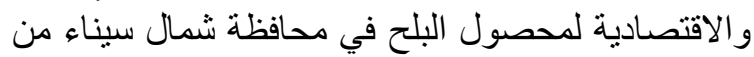
خلال القاء الضوء على الأهداف الفرعية التالية:

1- القياس الإحصائي لدوال إنتاج محصول البلح لاهلح بعينة الدر اسة في محافظة شمال سيناء.

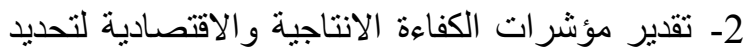
أهم العو امل المؤثرة على إنتاجية البلح.

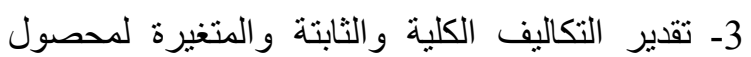
البلح بعينة الدراسة.

4- القياس الإحصائي لدوال تكاليف محصول البلح بعينة الدر اسة في محافظة شمال سيناء.

5- القاء الضوء على هو امش الربح، ومقاييس الكفاءة

الاقتصادية لمحصول البلح في في مختلف الفئل الفئات

الحيازية بعينة الدر اسة في محافظة شمال سيناء.

\section{الطريقة البحثية}

اعتمد البحث في تحقيق أهدافه على أساليب التحليل

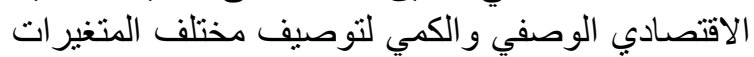

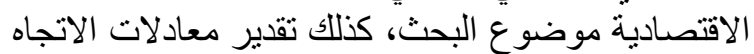

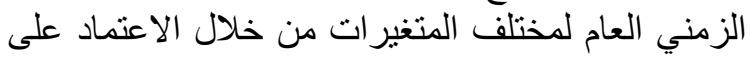

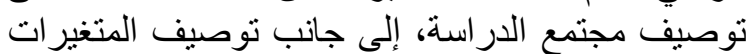
والعلاقات الاقتصادية سواء من ناحية الإنتاجية، وبنود الإدية

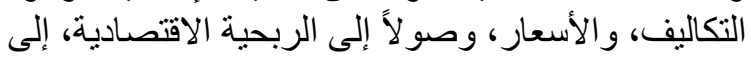

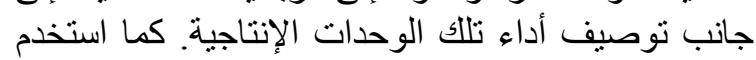

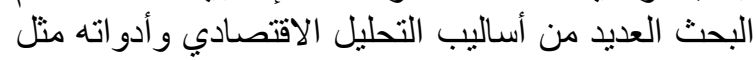

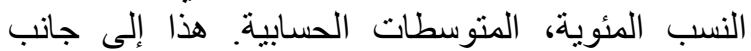

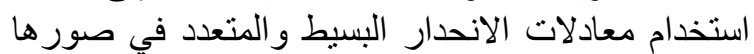

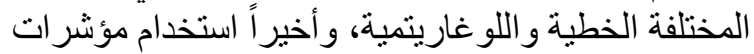
الكفاءة الاقتصادية لمزارع العينة.

\section{مصادر جمع البيانات}

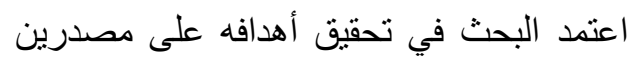

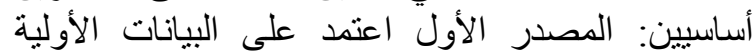

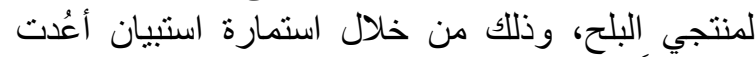

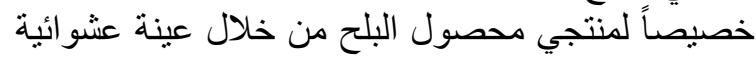

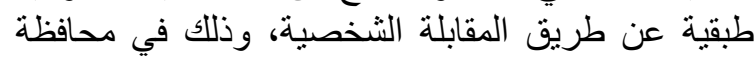

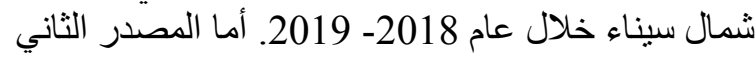

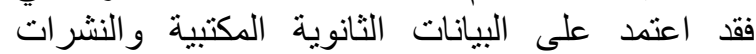

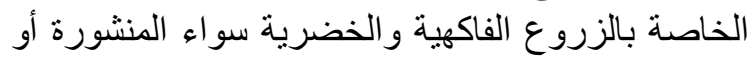

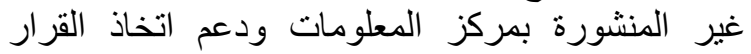

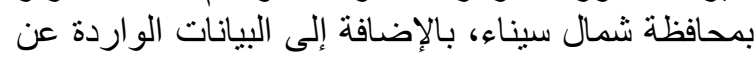


Tafily, et al. | SINAI Journal of Applied Sciences 10 (2) 2021 205-218

جدول 1. المساحة المثمرة لنخيل البلح وعدد الحائزين ومتوسط نصيب الحائز والوسط الهندسي والوسط الهندسي المعدل بمختلف المراكز الإدارية في محافظة شمال سيناء خلال متوسط الفترة 2014-2017.

\begin{tabular}{|c|c|c|c|c|c|c|c|}
\hline \multirow{2}{*}{ الوسط الهندس (\%) } & \multirow{2}{*}{ الوسط الهندسي } & \multirow{2}{*}{ متوسط نصيب } & \multicolumn{2}{|c|}{ عدد الحائزين } & \multicolumn{2}{|c|}{ المساحة المثرة } & \multirow{2}{*}{$\begin{array}{l}\text { الادر اية } \\
\text { المراكز }\end{array}$} \\
\hline & & & $(\%)$ & (حائز) & $(\%)$ & (ف) & \\
\hline 68.67 & 66.51 & 0.87 & 75.82 & 6364 & 58.34 & 5515.5 & بئر العبد \\
\hline 16.62 & 16.10 & 2.37 & 11.10 & 932 & 23.36 & 2208 & العريش \\
\hline 10.59 & 10.26 & 2.68 & 6.65 & 558 & 15.82 & 1495.5 & الشيخ زويد \\
\hline 3.69 & 3.57 & 0.42 & 5.84 & 490 & 2.18 & 206.0 & رفح \\
\hline 0.32 & 0.31 & 0.55 & 0.45 & 38 & 0.22 & 20.8 & نخل \\
\hline 0.11 & 0.11 & 0.64 & 0.14 & 12 & 0.08 & 7.7 & الحسنة \\
\hline 100 & 96.86 & 1.13 & 100 & 8394 & 100 & 9453.5 & جملة \\
\hline
\end{tabular}

المصدر: جُمعت وحُسبت من وزارة الزراعة واستصلاح الأراضي، مديرية الزراعة بمحافظة شمال سيناء، سجلات قسم الفاكهة، بيانات غير منشورة، 2018.

خلال منوسط الفترة (2014-2017). ومنه يتبين ان قرية

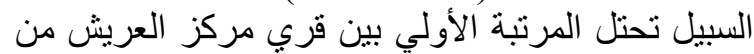

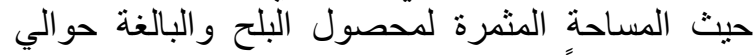

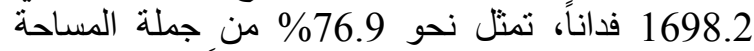
المثمرة في مركز العريش، كما تحتل أيضاً المرتبة الأولي

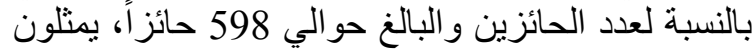
نحو 64.2\% من جملة عدد الحائزين في مركز العريش.

ثم تأتي قرية الميدان في المرتبة الثانية من حيث

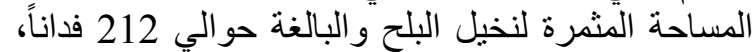

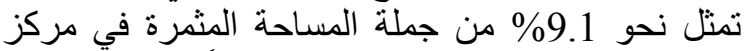

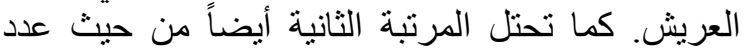

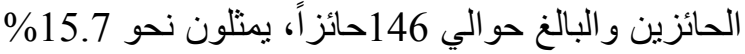

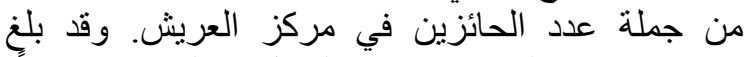

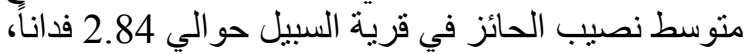

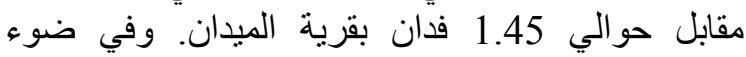
تقديرات الوسط الهندسي المعدل في قرئي الميدي السبيل

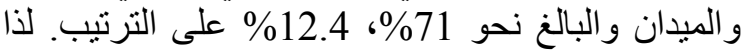

فقد تم اختبار هاتيين القريتين لتمثلان مركز العريش.

\section{تحديد حجم مزارع البلح في قري العينة}

في ضوء تقديرات الوسط الهندسي المعدل لقري فئري الدراسة في مركزي بئر العبد والعريش فقد تم الختيار

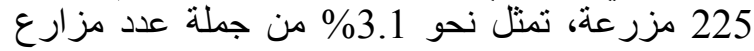

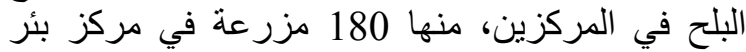

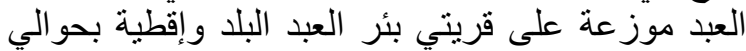

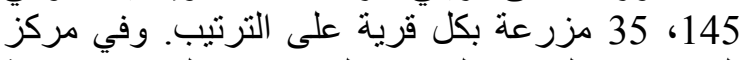

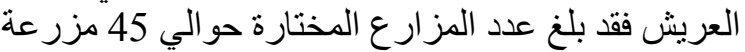

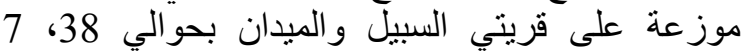
مزر عة بكل قرية على الترتيب.
اختيار قري العينة في مركزي الدراسة في محافظة

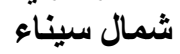
اختيار قري مركز بئر العبد

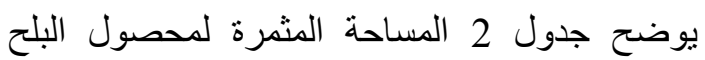

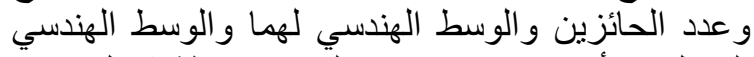

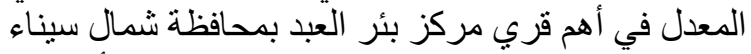

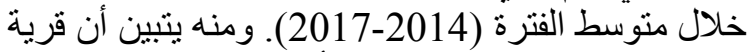
بئر العبد البلد تحتل المرتبة الأولي من حيث البران المساحة

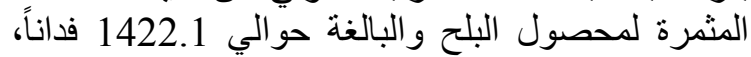
تمثل نحو 27.8\% من جملة المساحة المثمرة في مركز

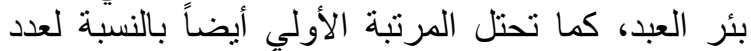

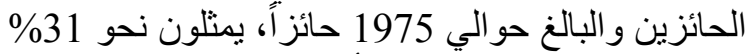
من جملة عدد الحائزين. ثم تأني قرية إقطية في التئية المرتبة

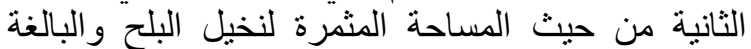
حو الي 414.9 فدان، تمثل نحو 8.1\% من جملة المثلة المساحة المثرة لنخيل البلح في باقي المراكز. كما تحتل من أيضاً

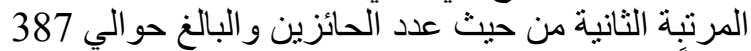

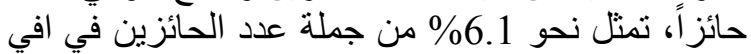

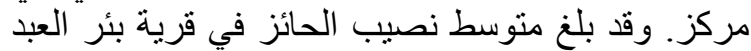

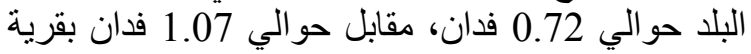

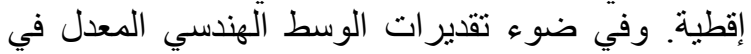

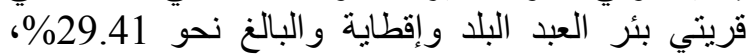
7.03\% على الترتيب. لذا فقد نم اختيار هاتين القريتين لتمثلان مركز بئر العبد.

\section{اختيار قري مركز العريش}

يوضح جدول 3 المساحة المثمرة لمحصول البلح

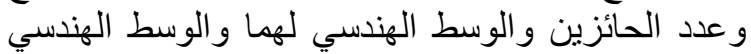
المعدل في قري مركز العريش بمحافظة شمال سيناء لوني 
جلول 2. المساحة المثرة لمحصول البلح وعدد الحائزين ومتوسط نصيب الحائز والوسط الهندسي والوسط الهندسي المعدل في أهم قري مركز بئر العبد بمحافظة شمال سيناء خلال متوسط الفترة 2014-2017.

\begin{tabular}{|c|c|c|c|c|c|c|c|}
\hline \multirow{2}{*}{ الوسط الهندسي (\%) } & \multirow{2}{*}{ الوسط الهندسي } & \multirow{2}{*}{ متوسط نصيب } & \multicolumn{2}{|c|}{ عدد الحائزين } & \multicolumn{2}{|c|}{ المساحة المثمرة } & \multirow{2}{*}{ بئرالعبد } \\
\hline & & & $(\%)$ & (حائز) & $(\%)$ & (ف) & \\
\hline 29.41 & 29.37 & 0.72 & 31.03 & 1975 & 27.8 & 1422.1 & بئر العبد البلا \\
\hline 7.03 & 7.02 & 1.07 & 6.08 & 387 & 8.11 & 414.9 & إقطية \\
\hline 6.17 & 6.16 & 0.74 & 6.41 & 408 & 5.92 & 302.8 & النجاح \\
\hline 5.45 & 5.44 & 0.87 & 5.24 & 333 & 5.64 & 288.5 & نجيلة \\
\hline 5.31 & 5.30 & 0.84 & 5.17 & 329 & 5.43 & 277.8 & قاطية \\
\hline 53.36 & 51.44 & 0.79 & 53.93 & 3432 & 49.06 & 2706.1 & جملة \\
\hline 46.64 & 48.44 & 0.96 & 46.07 & 2932 & 50.94 & 2809.4 & باقي القري \\
\hline 100 & 99.88 & 0.87 & 100 & 6364 & 100 & 5515.5 & جملة \\
\hline
\end{tabular}

المصدر: جُمعت وحُسبت من مديرية الزراعة بمحافظة شمال سيناء، الإدارة الزراعبة في مركز بئر العبد، سجلات قسم الفاكهة، إدارة النخيل،

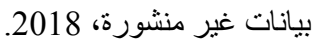

جلول 3. المساحة المثمرة لمحصول البلح وعدد الحائزين ومتوسط نصيب الحائز والوسط الهندسي والوسط الهندسي المعدل بقري مركز العريش في محافظة شمال سيناء خلال متوسط الفئ الفترة 2014-2017.

\begin{tabular}{|c|c|c|c|c|c|c|c|}
\hline \multirow{2}{*}{ الوسط الهندسي (\%) } & \multirow{2}{*}{$\begin{array}{l}\text { الوسط الهندم } \\
\text { (\%) }\end{array}$} & \multirow{2}{*}{ متوسط نصيب } & \multicolumn{2}{|c|}{ عدد الحائزين } & \multicolumn{2}{|c|}{ المساحة المثمرة } & \multirow{2}{*}{ قريش } \\
\hline & & & $(\%)$ & (حائز) & $(\%)$ & (ف) & \\
\hline 70.96 & 70.25 & 2.84 & 64.16 & 598 & 76.91 & 1698.2 & السبيل \\
\hline 12.38 & 12.26 & 1.45 & 15.66 & 146 & 9.06 & 212.0 & الميدان \\
\hline 8.02 & 7.94 & 1.58 & 9.66 & 90 & 6.42 & 141.8 & وادي العريش \\
\hline 5.75 & 5.69 & 1.78 & 6.54 & 61 & 4.94 & 108.8 & السكاسكة \\
\hline 1.42 & 1.4 & 1.57 & 1.72 & 16 & 1.14 & 25.2 & السلام \\
\hline 0.99 & 0.98 & 1.38 & 1.29 & 12 & 0.75 & 16.6 & الطويل \\
\hline 0.25 & 0.25 & 0.54 & 0.54 & 5 & 0.12 & 2.7 & الصقور \\
\hline 0.23 & 0.23 & 0.67 & 0.43 & 4 & 0.12 & 2.7 & الحفن \\
\hline 100 & 99.0 & 2.37 & 100 & 932 & 100 & 2208 & جملة \\
\hline
\end{tabular}


إنتاج محصول نخيل البلح، ويليه عامل كمية السماد

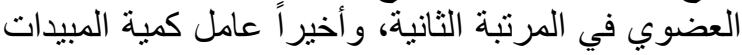

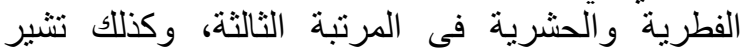
القياسات المتحصل عليها أن المرونة الإنتاجية للعوامل المبل

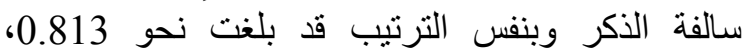

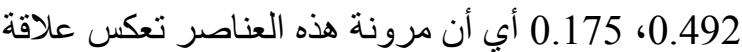

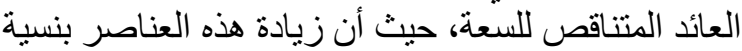

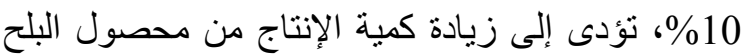

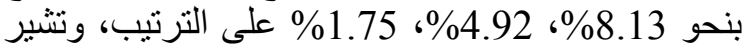

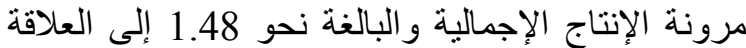

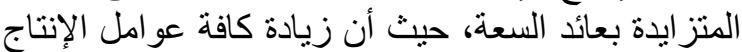

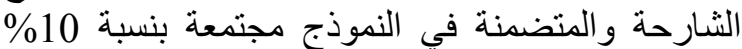

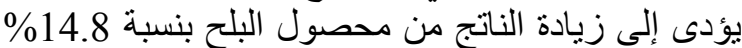
أي أن الإنتاج يتم في المرحلة الأولى (غير الاقلى الإنصادية)

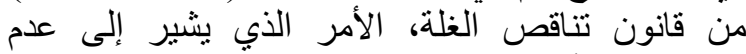

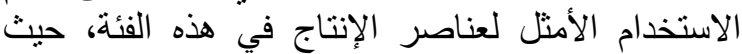

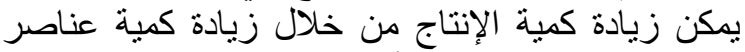

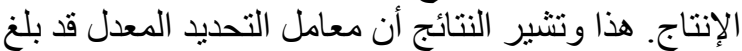

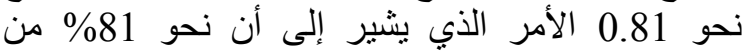

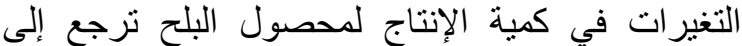

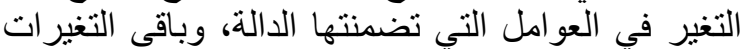

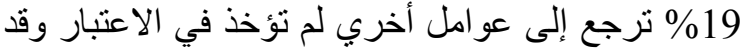

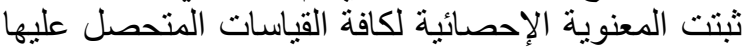
لدالة الإنتاج عند المستوي الإحتمالي 0.01، وبلغت الإنة قيمة عالية

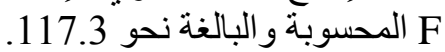

\section{القياس الإحصائى لالة إنتاج محصول البلح في الفئة} الحيازية الثانية (1-2 فدانيان لاندان

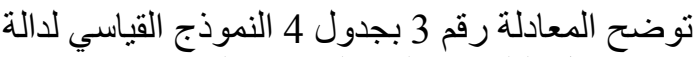

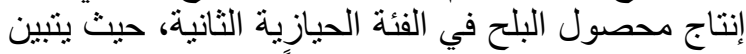

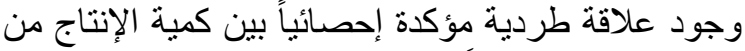

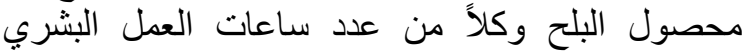

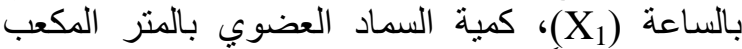
باللتر (X)، وأخيراً عامل كمية المبيدات الفطرية والحشرية

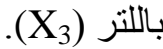

كما تبين أن عامل عدد ساعات العمل البشري يحتل البرائ المرتبة الأولى من حيث التأثير المعنوي على على كمية إنتاج التئي

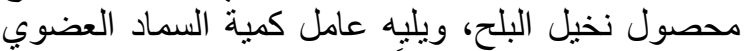
في المرتبة الثانية، وأخيراً عامل كمية المبيدات الفطرية الفية الفية الفية

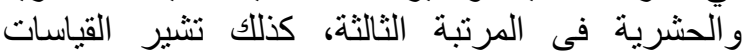
المتحصل عليها أن المرونة الإنتاجية للعو امل سالفة الذكر

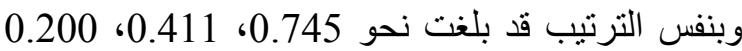
أي أن مرونة هذه العناصر تعكس علاقية العنة العائد المتناقص

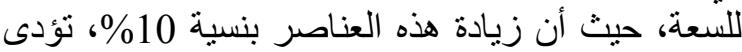

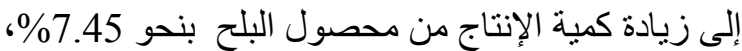

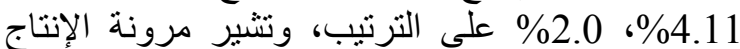

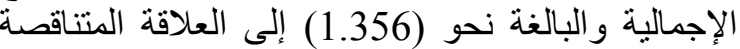

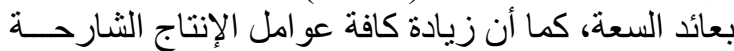

وذللك وفقا للمعادلة (الصياد، ):

$\mathrm{N}$

$\mathrm{n}=$

$(\mathrm{N}-1) \mathrm{B}^{2}+1$

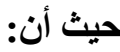

n $=$ = حجم العينة الممثلة للمجتمع أو الحائزين.

جملة مجتمع الحائزين لنخيل البلح موضع الدر اسة.

B = خطأ التقدير (0.10).

القياس الأحصائي لاوال إنتاج محصول البلح بعينة

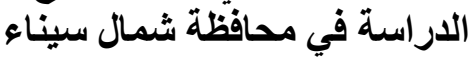

يتتاول هذا الجزء من البحث تقدير دوال الإنتاج

لمحصول البلح بهدف التعرف على الكفاءة الإنتاجية لهذا لهذاج

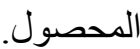

القياس الإحصائي لاوال إنتاج محصول البلح في مختلف الفئات الحيازية بالعينة

أكدت نتائج البحث الميدانية أن كمية الإنتاج (qi)

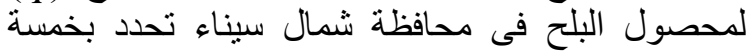

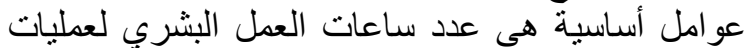

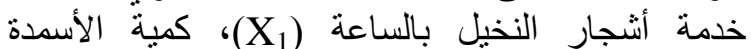
العضوية المضافة بالمثر المكعب (X) (X)، كمية المبيدات

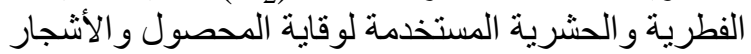

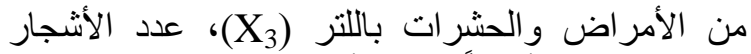

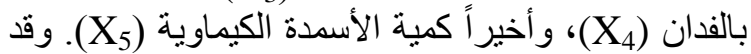

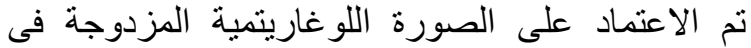
تقدير دو ال الإنتاج، حيث أعطت الإنة أفضل النتائج من حيثة

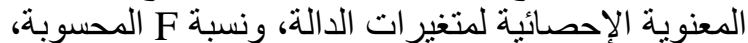

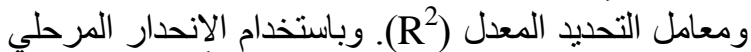

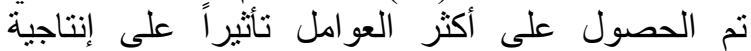

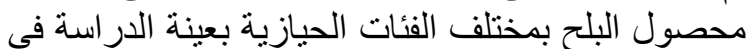

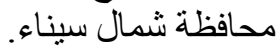

ويوضح جدول 4 النماذج القياسية لأهم العوامل المؤثرة على إنتاجية محصول البلح بمختلف الفئات الحيازية بعينة العينة الدر اسة فى محافظة شمال سيناء ومنه يتبين أن:

القياس الإحصائى لدالة إنتاج محصول البلح في الفئلة الحيازية الأولى (أقلّ من فذان) لإناج

توضح المعادلة رقم 2 بجدول 4 النموذج القياسي لدالة التاني إنتاج محصول البلح في الفئة الحيازية الأولى، حيث ئن يتينين وجود علاقة طردية مؤكدة إحصائياً بين كمية الإنتاج من الإن

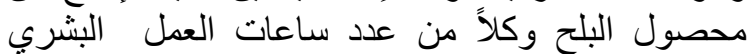

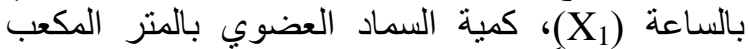

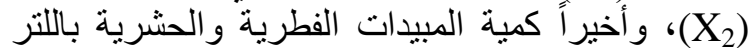

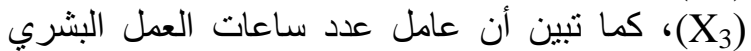
يحتل المرتبة الأولى من حيث التأثير المعنوي على كميةٍ 
جدول 4. النماذج القياسية لأهم العوامل المؤثرة على إنتاج محصول البلح بمختلف الفئات الحيازية بعينة الدراسة في

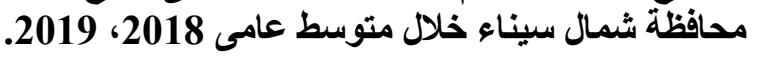

\begin{tabular}{|c|c|c|c|c|c|}
\hline المحسوبة & $\mathbf{R}^{12}$ & 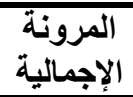 & النموذج القياسي لدالة الإنتاج & الحيازة الفدانية & 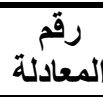 \\
\hline$* * 117.3$ & 0.81 & 1.48 & 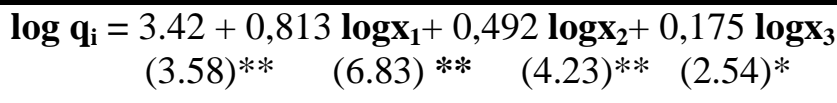 & (أقلَّ من فذانى) & 2 \\
\hline$* * 86.9$ & 0.84 & 1.356 & 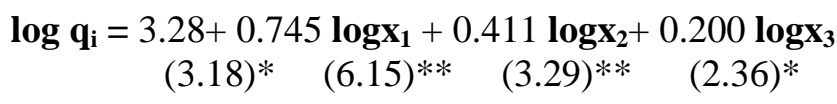 & الفئة الثانية & 3 \\
\hline$* * 57.2$ & 0.88 & 1.218 & 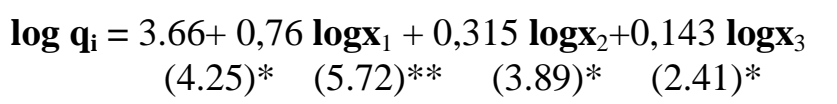 & (2فئة الثالثة & 4 \\
\hline
\end{tabular}

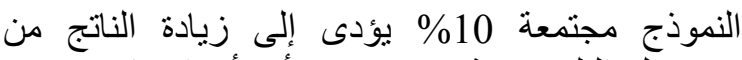
محصول البلح بنسبة 12.18\%، أب أن الإنتاج يتم في الإنج المرحلة الأولى (غير الاقتصادية) من قانون تناقص الإنص الغلة.

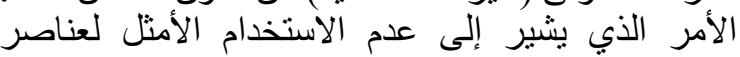

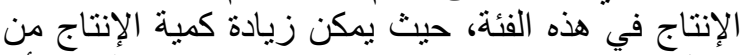

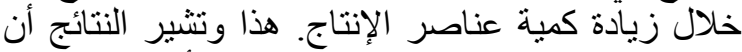

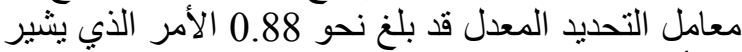

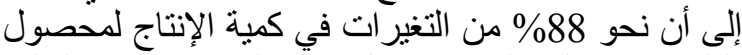

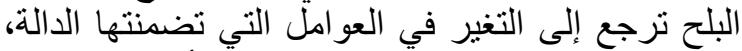

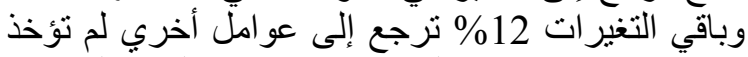

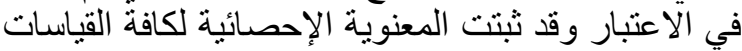

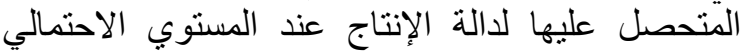
0.01، وبلغت قيمة F المحسوبة نحو 57.2.

مؤشرات الكفاءة الإتتاجية والإقتصادية لأهم العناصر المستخدمة لإنتاج محصول الإنتاجل والأح العينة

$$
\text { عنصر عدد ساعات العمل البشري }
$$

باستعر اض بيانات جدول 5 و الذي يوضح أهم مؤشرات الهري

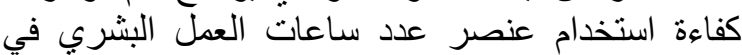
إنتاج محصول البلح بالفئات الحيازية الثلاثة في محافظة الثئة

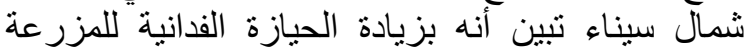

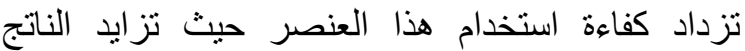

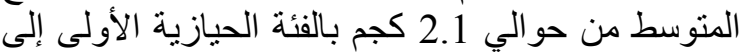

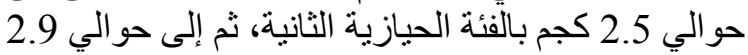

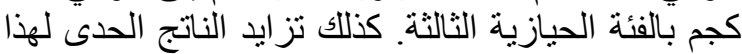

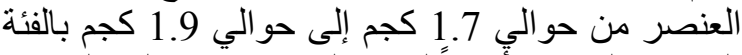
الحيازية الثانية، وأَخير أإلي حو الي 2.2 كجم بالفئة الحبازية

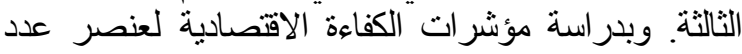

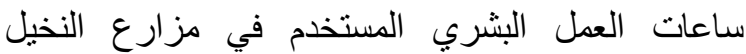

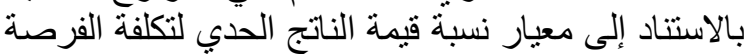

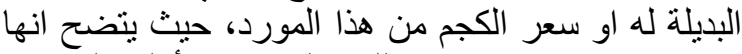

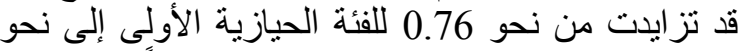
0.84 للفئة الحيازية الثانية، وقد اقتربت نماماً من الواحد الثد

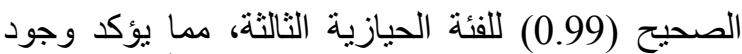
إسر اف فى استخدام هذا العنصر في الفئتين الأولى والثانية.
و المتضمنة في النموذج مجنمعة بنسبة 10\% يؤدى إلى ألى أنى

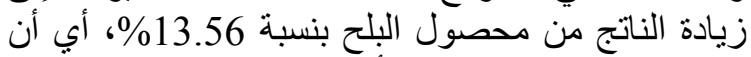

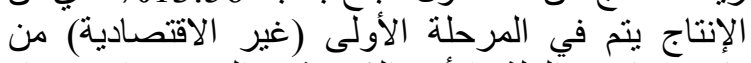

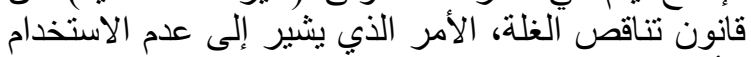

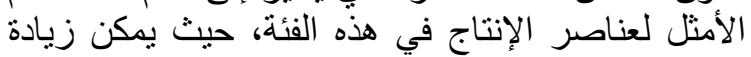

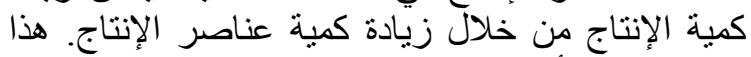

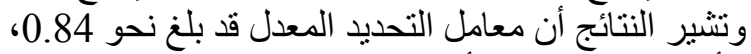

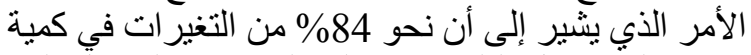

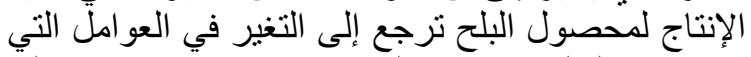

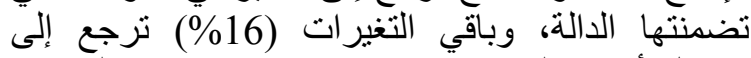

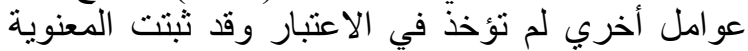

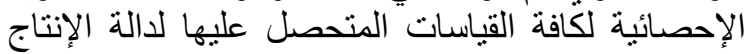

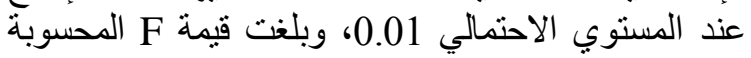
نحو (86.9).

القياس الإحصائى لدالة إنتاج محصول البلح في الفئة (الحيازية الثالثثة (2 فدان فأكثر)

توضح المعادلة رقم 4 بجدول 4 النموذج القياسى التهى لدالة إنتاج محصول البلح في الفئة الحيازية الثالثنة، حيث الثيث

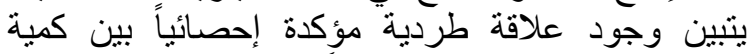

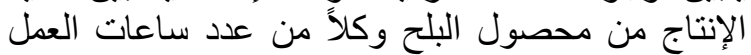

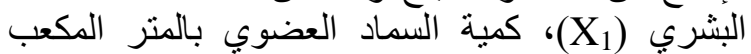

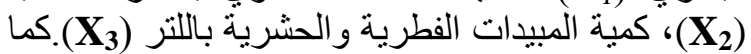

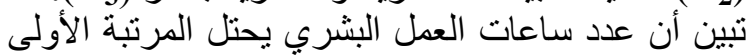

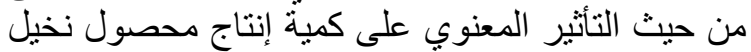

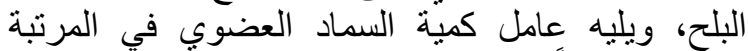

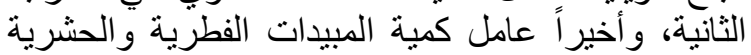

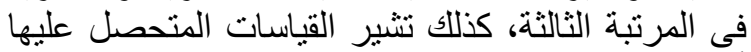

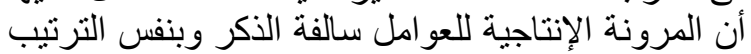

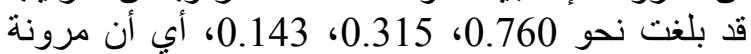

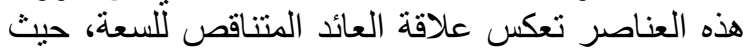

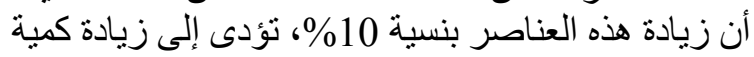

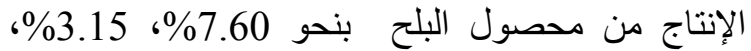

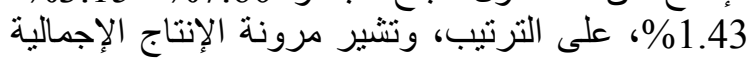

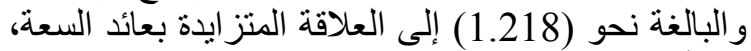

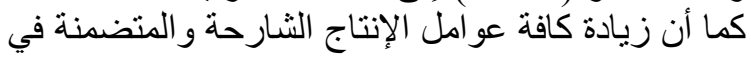


Tafily, et al. | SINAI Journal of Applied Sciences 10 (2) 2021 205-218

جدول 5. مؤشرات الكفاءة الاتتاجية والاقتصادية لعنصر عدد ساعات العمل البشري المستخدمة بمزارع البلح بمختلف

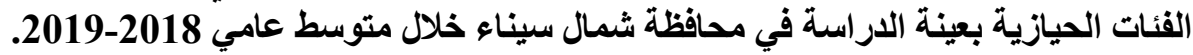

\begin{tabular}{|c|c|c|c|}
\hline الفئة الحيازية الثالثَة & الفئة الحيازية الثانية & (الفئة الحيازية الأولى & مؤشرات الكفاءة \\
\hline & & & مؤشرات الكفاءة الاتتاجية \\
\hline 0.760 & 0.745 & 0.813 & المرونة الانتاجية \\
\hline 2.895 & 2.506 & 2.077 & الناتج المتوسط (كجم) \\
\hline 2.2 & 1.867 & 1.689 & الناتج الحدي (كجم) \\
\hline & & & مؤشرات الكفاءة الاقتصادية \\
\hline 4.5 & 4.5 & 4.5 & سعر الكجم من النخيل الخام (جنيه) \\
\hline 9.9 & 8.4 & 7.6 & قيمة الناتج الحدي (جنيه) \\
\hline 10 & 10 & 10 & تكلفة الساعة (جنيه) \\
\hline 0.99 & 0.84 & 0.76 & معامل الكفاءة الاقتصادية \\
\hline
\end{tabular}

المصدر: جُمعت وحُسبت من بيانات عينة الدر اسة.

حوالي 640 كجم بالفئة الحيازية الأولى إلى حوالى الئي

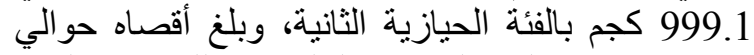

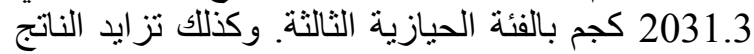
الحدى لهذا العنصر من حوالي 112 كجم إلى حولى حوالئي

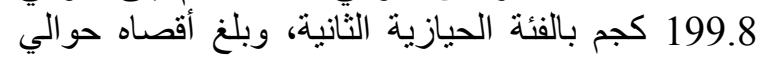
290.5

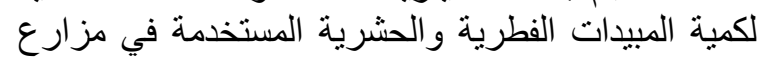

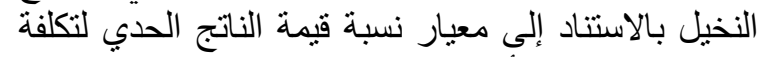

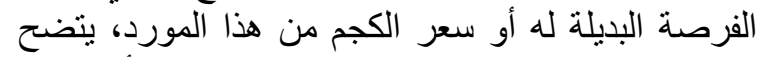

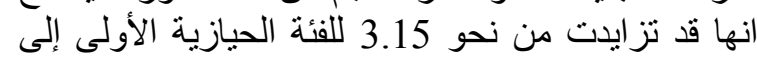

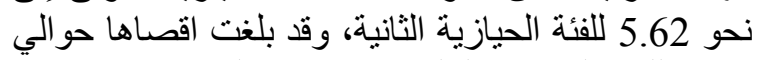

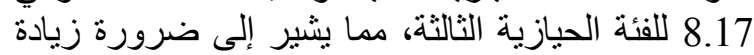

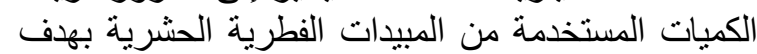

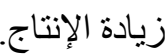

\section{تكاليف إنتاج محصول البلح بعينة الاراسة فى محافظة شمال سيناء}

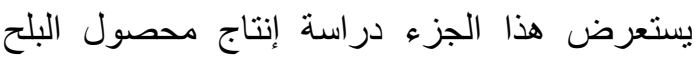

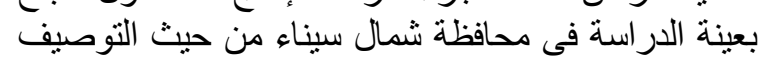

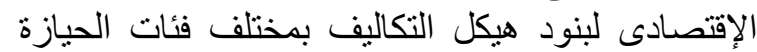

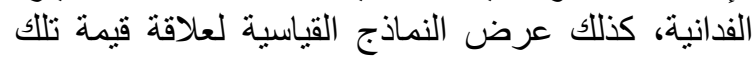

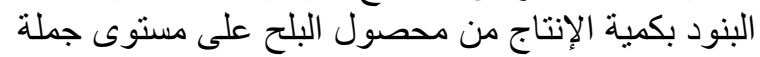

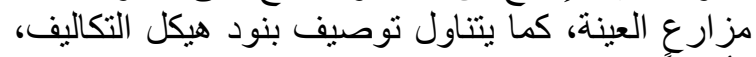

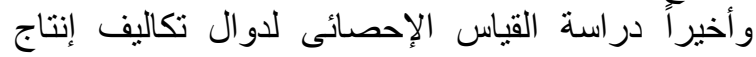

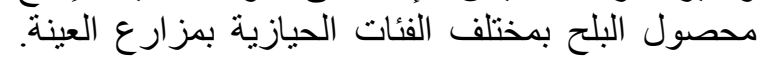

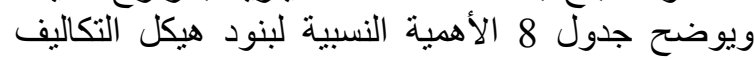

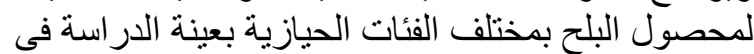
محافظة شمال سيناء ومنه يتبين أن:
عنصر السماد العضوى

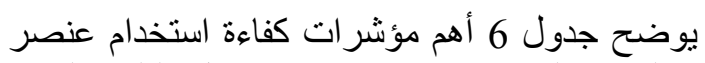
كمية السماد العضوى في إنتاج محصن فئرل كفاءول البلح بالفئات

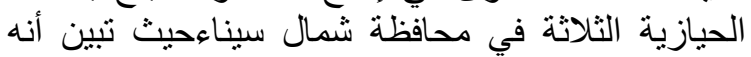

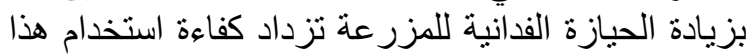
العنصر حيث تزايد الناتج المتوسط من حوالئ لإني 155.4

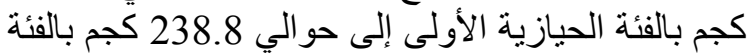

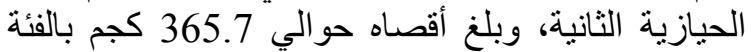

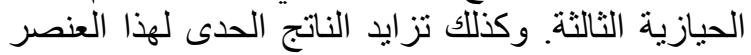

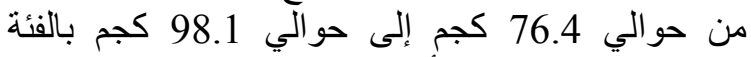
الحيازية ألثانية، وبلغ أقصاه حوالئ 16.4 115.2كجم بالفئة

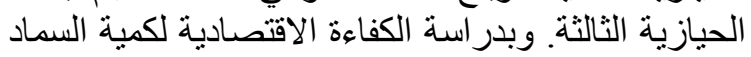
العضوي المستخدم في مز ارعة النخيلة النيل بالاستتاد إلى معيار

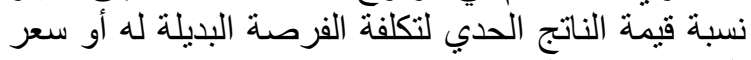

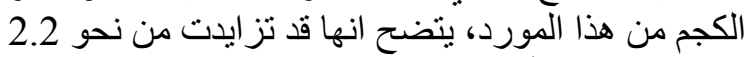
للفئة الحبازية الأولى إلى نحو 2.8 للفئة الحيازية الثانية،

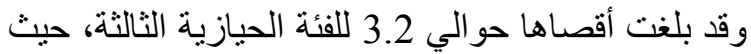
أخذت قيمة موجبة وأكبر من الوالي الحد الصحيح في الفئات

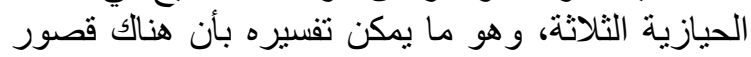

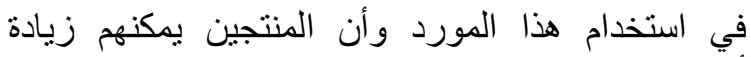
أرباحهم من خلال التوسع في استخدام هذا العنصر.

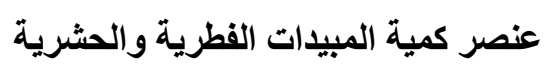

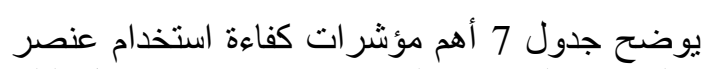

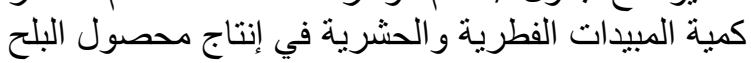

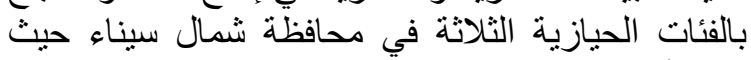

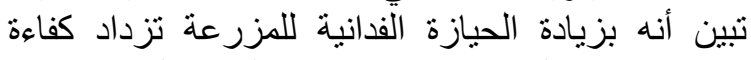
استخدام هذا العنصر حيث تزازة ايد الناتج المتوسط من لزئ 
جول 6. مؤشرات الكفاءة الانتاجية والاقتصادية لكمية السماد العضوي المستخدمة في مزارع النخيل بمختلف الفئات

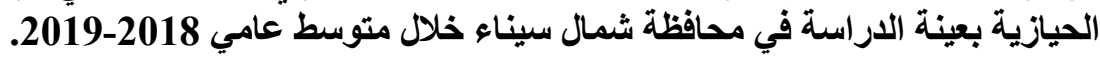

\begin{tabular}{|c|c|c|c|}
\hline الفئة الحيازية الثُالثة & الفئة الحيازية الثانية & (أقلّة من فيازية الأولى & مؤشرات الكفاءة \\
\hline & & & مؤشرات الكفاءة الانتاجية \\
\hline 0.315 & 0.411 & 0.492 & المرونة الانتاجية \\
\hline 365.714 & 238.766 & 155.374 & الناتج المنوسط (كجم) \\
\hline \multirow[t]{2}{*}{115.2} & 98.133 & 76.444 & الناتج الحدي (كجم) \\
\hline & & & مؤشرات الكفاءة الاقتصادية \\
\hline 4.5 & 4.5 & 4.5 & سعر الكجم من النخيل الخام (جنيه) \\
\hline 548.4 & 441.6 & 344 & قيمة الناتج الحدي (جنيه) \\
\hline 160 & 160 & 160 & سعر السماد (م³/ جنيه) \\
\hline 3.24 & 2.76 & 2.15 & معامل الكفاءة الاقتصسادية \\
\hline
\end{tabular}

جدول 7. مؤثرات الكفاءة الإنتاجية والاقتصادية لكمية المبيدات الفطرية والحشرية المستخدمة في مزارع النخيل بمختلف الفئات الحيازية بعينة الدراسة في محافظة شمال سيناء خلال متوسط والفية عامي 2018-2019.

\begin{tabular}{|c|c|c|c|}
\hline الفئة الحيازية الثالثة & الفئة الحيازية الثانية & (أقلَّلة من فيازية الأولى & مؤشرات الكفاءة \\
\hline & & & مؤشرات الكفاءة الإنتاجية \\
\hline 0.143 & 0.200 & 0.175 & المرونة الانتاجية \\
\hline 2031.293 & 999.11 & 640.0 & الناتج المنوسط (كجم) \\
\hline \multirow[t]{2}{*}{290.489} & 199.822 & 112 & الناتج الحدي (كجم) \\
\hline & & & مؤشرات الكفاءة الاقتصادية \\
\hline 4.5 & 4.5 & 4.5 & سعر الكجم من النخيل الخام (جنيه) \\
\hline 1307.2 & 899.2 & 504 & قيمة الناتج الحدي (جنيه) \\
\hline 160 & 160 & 160 & سعر اللتر من المبيد (جنيه) \\
\hline 8.17 & 5.62 & 3.15 & معامل الكفاءة الاقتصادية \\
\hline
\end{tabular}


جلول 8. بنود هيكل التكاليف لمحصول البلح بمختلف الفئات الحيازية بعينة الدراسة في محافظة شمال سيناء خلال

متوسط عامي 2018-2019.

\begin{tabular}{|c|c|c|c|c|c|c|c|c|c|}
\hline & \multicolumn{2}{|c|}{ جملة العينة } & \multicolumn{2}{|c|}{2} & \multicolumn{2}{|c|}{ فان } & \multicolumn{2}{|c|}{ أقل من فدان } & \multirow[b]{2}{*}{ بنود هيكل التكاليف } \\
\hline$(\%)$ & م. نصيب & م. نصديب & مُ نصيب & م. نصيب & م. نصيب & م. نصيب & م. نصبيب & م. نصيب & \\
\hline & & & & & & & & & التكاليف الثابتة \\
\hline 16.45 & 0.38 & 1512.7 & 0.37 & 1403.9 & 0.38 & 1488.2 & 0.039 & 1547.2 & الايجار السنوي \\
\hline 8.40 & 0.20 & 772.3 & 0.17 & 654.0 & 0.19 & 732.3 & 0.21 & 816.5 & العمالة العائلية \\
\hline 24.84 & 0.58 & 2285.0 & 0.54 & 2057.9 & 0.57 & 2220.5 & 0.60 & 2363.7 & جملة \\
\hline & & & & & & & & & التكاليف المتغيرة \\
\hline 30.86 & 0.73 & 2838.6 & 0.68 & 2601.0 & 0.70 & 5421.7 & 0.75 & 2937.4 & جمع المحصول \\
\hline 10.31 & 0.24 & 948.6 & 0.24 & 898.2 & 0.24 & 932.2 & 0.25 & 967.1 & التلقيح \\
\hline 8.11 & 0.19 & 746.3 & 0.18 & 691.8 & 0.19 & 732.6 & 0.19 & 764.3 & التقليم \\
\hline 6.37 & 0.15 & 586.1 & 0.14 & 541.1 & 0.15 & 586.1 & 0.15 & 595.3 & التدنية \\
\hline 4.81 & 0.11 & 442.8 & 0.11 & 401.2 & 0.11 & 432.6 & 0.12 & 456.4 & الخف \\
\hline 60.47 & 1.42 & 5562.4 & 1.35 & 5133.3 & 1.39 & 5421.7 & 1.45 & 5720.5 & العمالة المؤجرة \\
\hline 10.53 & 0.25 & 968.3 & 0.24 & 901.3 & 0.24 & 943.1 & 0.25 & 994.6 & سماد عضوي \\
\hline 4.16 & 0.10 & 382.6 & 0.08 & 321.2 & 0.10 & 376.5 & 0.10 & 398.2 & مبيدات فطريـة وحشرية \\
\hline 75.16 & 1.77 & 6913.3 & 1.67 & 6355.8 & 1.73 & 6741.3 & 1.81 & 7113.3 & جملة \\
\hline 100 & 2.35 & 9198.3 & 2.21 & 8413.7 & 2.30 & 8961.8 & 2.41 & 9477.0 & التكاليف الكلية \\
\hline
\end{tabular}

المصدر: جُمعت وحُسبت من استمار ات الاستيبان الخاصة بالدراسة الميدانية.

7113.3 جنيهاً للفدان، بما يوازى حو الي 1.81 جنيه/ كجم من محصول البلح كد أقصى في في الفئة الفئ الحيازية الأولى (أقل من فدان)، هذا وقد بلغ المتوسط العام لجملة

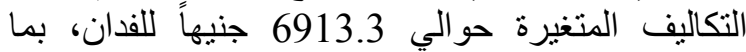

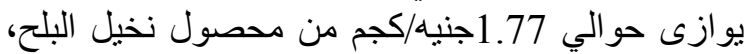

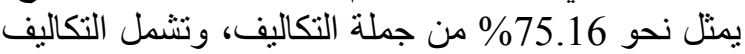
المتغيرة لإنتاج محصول البلح كلا من العمالة المؤجرة

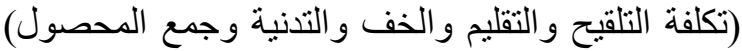
و السماد العضوي و المبيدات الفطرية و الحشرية.

تعتبر دو ال التكاليف ذات أهمية بالغة بالنسبة للتخطيط

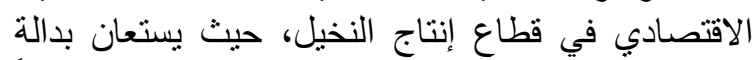

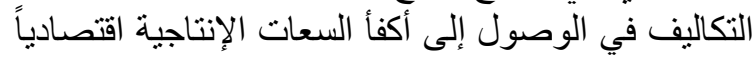

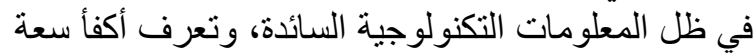

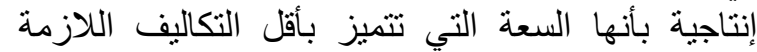

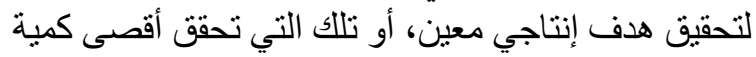

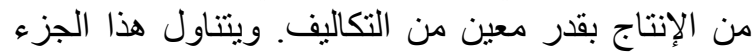

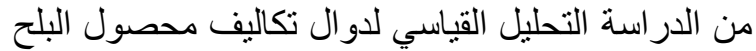
في المدى القصير والمدي الطويل بعينة الدراسة فى لئ الطي

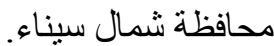

\section{التكاليف الثابتة}

بلغ إجمالي التكاليف الثابتة لمحصول البلح أدنى قيمة

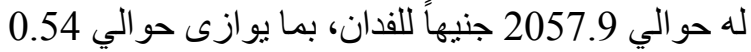

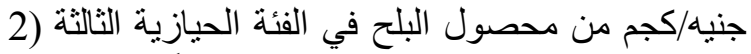

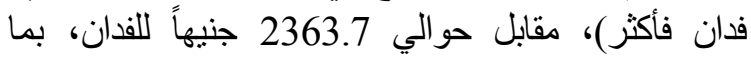
يو ازى حوالي 0.60 جنيه/كجم من محصول البلح كحد أقصى في الفئة الحيازية الأولى (أقل من فدان)، هذا ولئ وقد

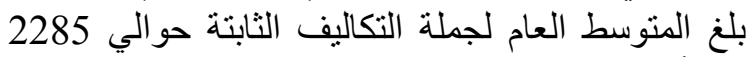
جنيهاً للفذان، بما يوازى حوالي 0.58 جنيه/كجم من محصول نخيل البلح، يمثل نحو 24.84\% من جملة

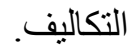

\section{التكاليف المتغيرة}

باستعر اض الأرقام الواردة بجدول 8 سابق الإشارة

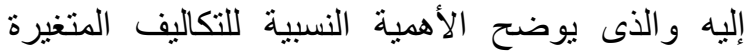
وبنودها لمحصول البلح ومنه يتبين أن التكاليف المتغيرة

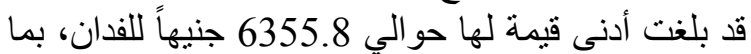

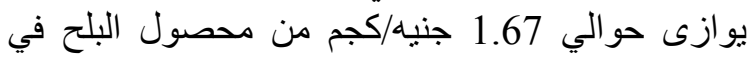
الفئة الحيازية الثالثة (2 فدان فأكثر)، مقابل حولي الئ في 
بالصفر أمكن الحصول على الحجم الأمثل للإنتاج و البالغ

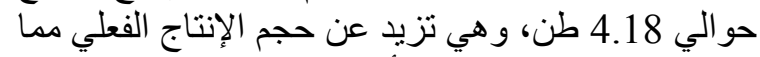

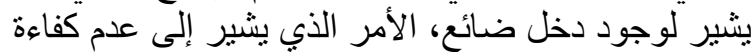

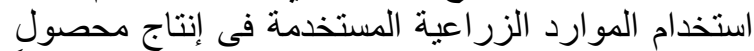

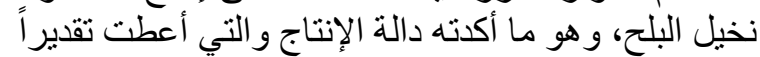

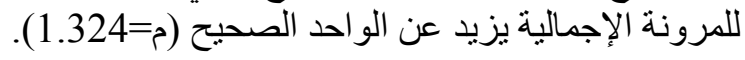

دالة تكاليف الفئة الحيازية الثالثة (2 فدان فأكثر)

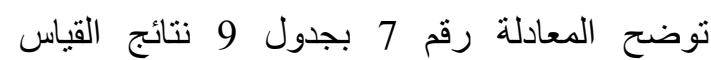

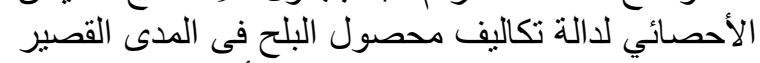

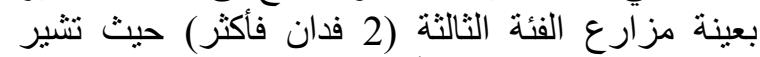

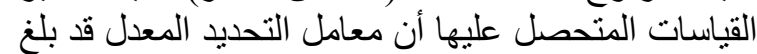

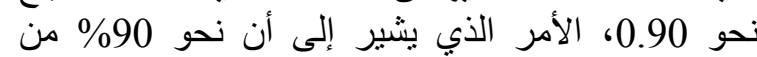

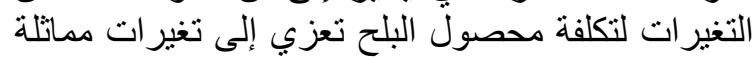

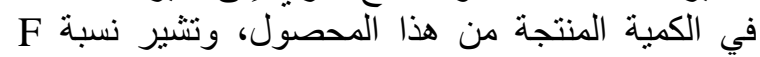
المحسوبة و البالغة نحو 63.8.

وبمساو اة دالة التكاليف الحدية الموضحة بالمعادلة رقم

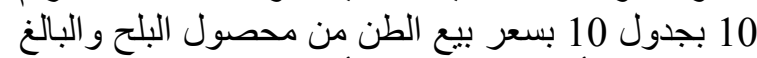
حوالي 4.5 ألف جنيه، يتبين أن كمية الإنتاج المعظمة

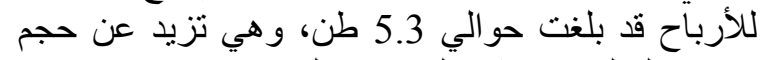
الإنتاج الفعلي مما يشير لوجي لود دخل طن ضائع.

وبايجاد المشتقة الأولى لدالة منوسط التكاليف الكلية

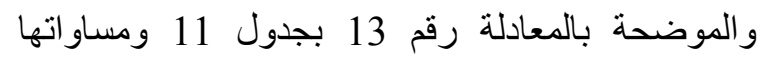

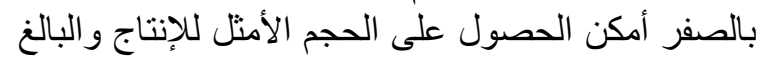

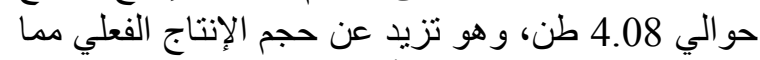

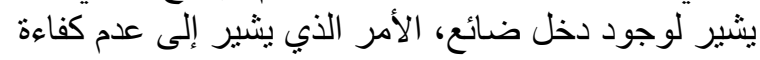

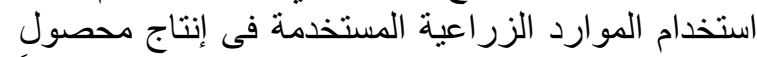

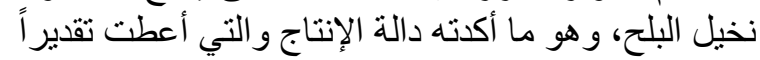

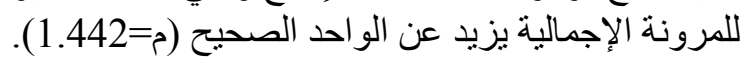

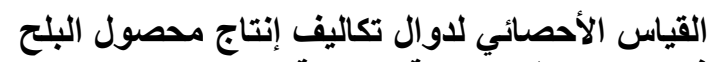
فى المدى الطويل بعينة الدراسئة الدالئ

توضح المعادلة رقم (14) نتائج القياس الإحصائي

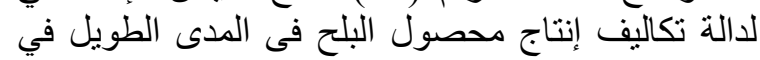
جملة مز ار ع العينة بمحافظة شمال سيناء.

$\mathbf{T c i}=4.95+1.69 \mathbf{q}_{\mathbf{i}}-0.516 \mathbf{q}_{\mathbf{i}}{ }^{2}+0.094 \mathbf{q}_{\mathbf{i}}{ }^{3} \ldots$ (14)

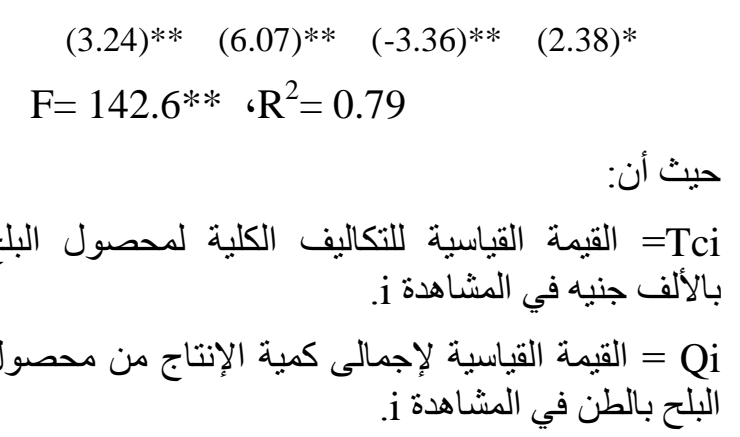
225 لجملة العينة. ، 2 ، $1=\mathrm{i}$

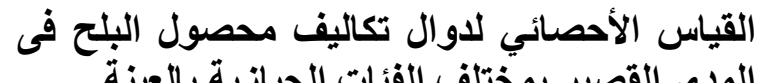
المدى القصير بمختلف الفئات الحيازية بالعينة

يوضح جدول 9 النماذج القياسية لدوال التكاليف الإجمالية لمحصول البلح بمختلف الفئات الحيازية لئية بعينة الدراسة فى المدى القصير في محافظة شمال سيناء ومنه بله بلهن

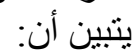

\section{دالة تكاليف الفئة الحيازية الأولى (أقل من فدان)}

توضح المعادلة رقم 5 بجدول 9 نتائج القياس

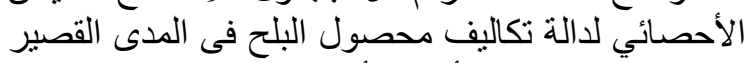

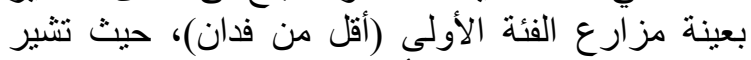

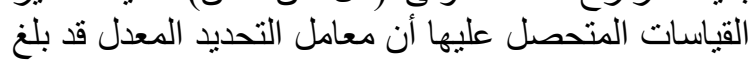

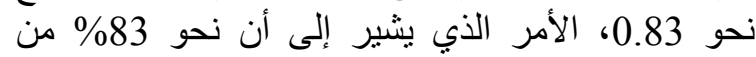

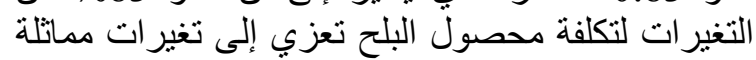

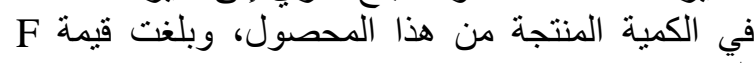

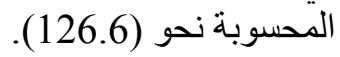

وبمساو اة دالة التكاليف الحدية الموضحة بالئ بالمعادلة رقم

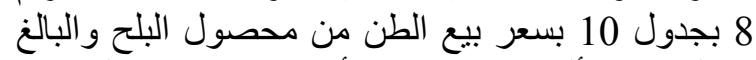

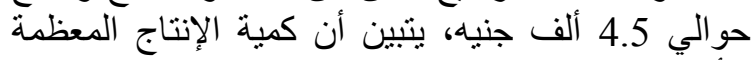

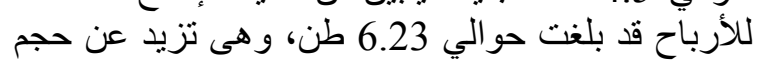

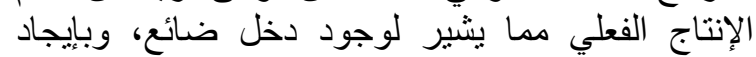

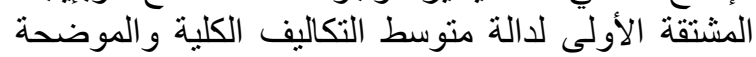

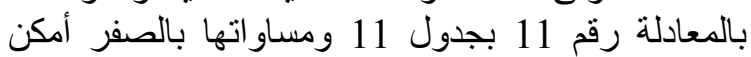

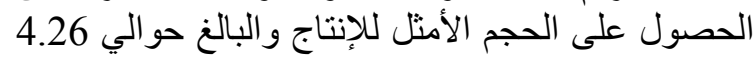

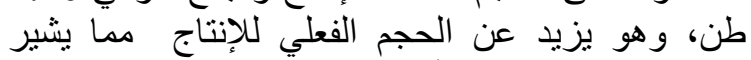

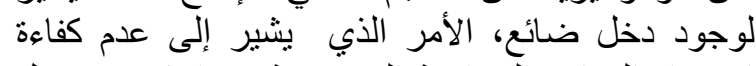

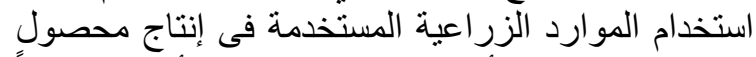

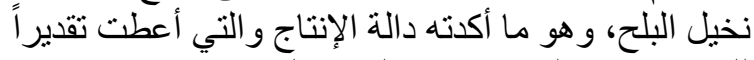

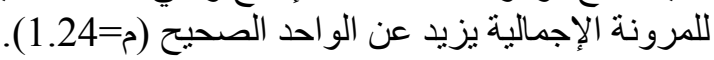

دالة تكاليف الفئة الحيازية الثانية (1-2 فدان)

توضح المعادلة رقم 6 بجدول 9 نتائج القياس

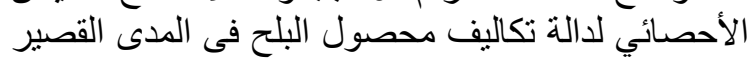

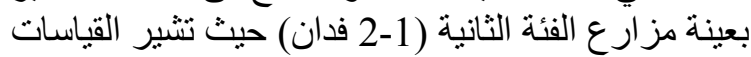

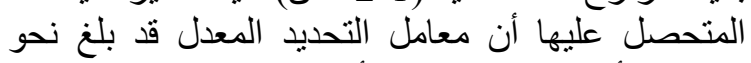

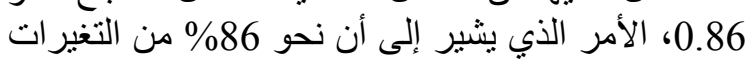

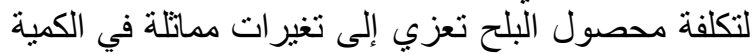
المنتجة من هذا المحصول، وتشئير نسية F

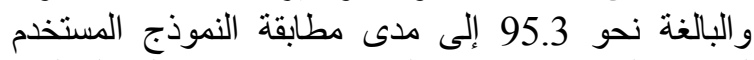
لطبيعة البيانات موضع القياس. وبمساواة دالة التئلة التكاليف

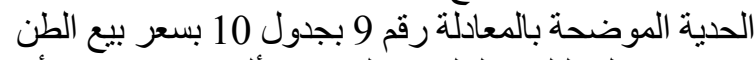

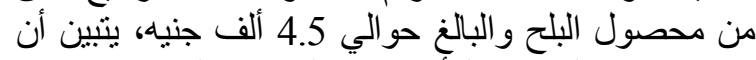

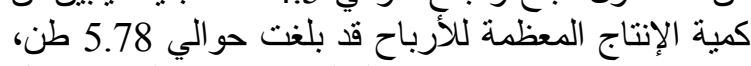
وهي تزيد عن حجم الإنتاج الفعلي مما يشير لوني لوجود دخل ضائع.

وبايجاد المشتقة الأولى لدالة متوسط التكاليف الكلية

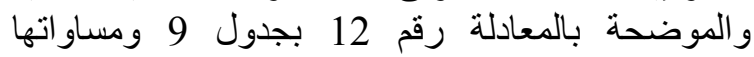


Tafily, et al. | SINAI Journal of Applied Sciences 10 (2) 2021 205-218

جلول 9. النماذج القياسية لدوال التكاليف الإجمالية لمحصول البلح فى المدى القصير بمختلف الفئات الحيازية بعينة

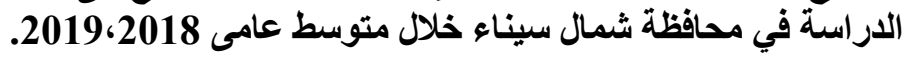

\begin{tabular}{|c|c|c|c|c|}
\hline F المحسوبة F & $\mathbf{R}^{1 / 2}$ & النماذج القياسية لدوال التكاليف الإجمالية & الحيازة الفدانية & رقم المعادلة \\
\hline$* * 126.6$ & 0.83 & $\begin{array}{c}\text { Tci }=3.19+\mathbf{1 . 6 8 q _ { i }}-\mathbf{3 . 4 4} \mathbf{q}_{\mathbf{i}}{ }^{2}+0.061 \mathbf{q}_{\mathbf{i}}{ }^{3} \\
(2.64)^{*}(5.64)^{* *}(-3.86)^{* *}(2.53)^{*}\end{array}$ & (أقل من فدان) & 5 \\
\hline$* * 95.3$ & 0.86 & $\begin{array}{c}\mathbf{T c i}=5.01+\mathbf{1 . 0 5} \mathbf{q}_{\mathbf{i}}-0.316 \mathbf{q}_{\mathbf{i}}{ }^{2}+0.072 \mathbf{q}_{\mathbf{i}}{ }^{3} \\
(2.36)^{*}(6.12)^{* *}(-3.16)^{* *}(2.68)^{*}\end{array}$ & الفئة الثانية & 6 \\
\hline$* * 63.8$ & 0.90 & $\begin{aligned} \mathbf{T c i} & =3.46+2.45 \mathbf{q}_{\mathbf{i}}-0.779 \mathbf{q}_{\mathbf{i}}{ }^{2}+0.121 \mathbf{q}_{\mathbf{i}}{ }^{3} \\
(2.89)^{*}(6.31)^{* *} & (-3.28)^{*}(2.76)^{*}\end{aligned}$ & (2فانة فأكثر) & 7 \\
\hline \multicolumn{5}{|c|}{ 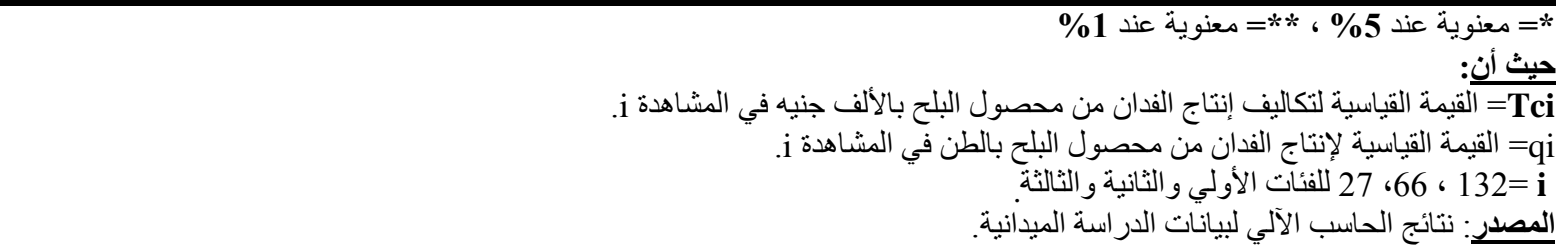 } \\
\hline
\end{tabular}

جدول 10. النماذج القياسية لدوال التكاليف العدية لمحصول البلح فى المدى القصير بمختلف الفئات الحيازية بعينة الاراسة في محافظة شمال سيناء خلال متوسط عامى 2018، 2019.

\begin{tabular}{|c|c|c|}
\hline دالة التكاليف الحلية & الفئات الحيازية & رقم المعادلة \\
\hline $\mathrm{Mc}_{\mathrm{i}}=1.68-0.688 \mathrm{q}_{\mathrm{i}}+0.183 \mathrm{q}_{\mathrm{i}}^{2}$ & (أقل من فذانَ) & 8 \\
\hline $\mathrm{Mc}_{\mathrm{i}}=1.21-0.632 \mathrm{q}_{\mathrm{i}}+0.216 \mathrm{qi}^{2}$ & الفئة الثانية & 9 \\
\hline $\mathrm{Mc}_{\mathrm{i}}=2.45-1.558 \mathrm{q}_{\mathrm{i}}+0.363 \mathrm{q}_{\mathrm{i}}^{2}$ & (2فذانة فأكثر) & 10 \\
\hline
\end{tabular}

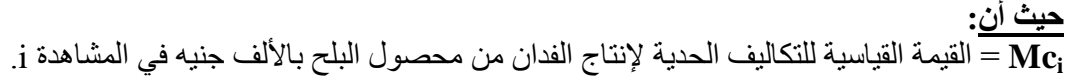

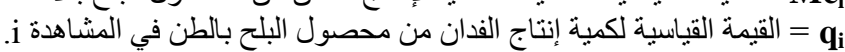

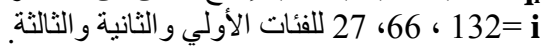
المصدر: جُمعت وحُسبت من المعادلات الواردة بجدول 10.

جدول 11. النماذج القياسية لدوال متوسط التكاليف الكلية لمحصول البلح فى المدى القصير بمختلف الفئات الحيازية بعينة الدراسة فى محافظة شمال سيناء خلال متوسط عامى 2018، 2019.

\begin{tabular}{|c|c|c|}
\hline دالة متوسط التكاليف الكلية & الفئات الحيازية & المعادلة \\
\hline $\operatorname{ATc}_{\mathrm{i}} 3.19 / \mathrm{q}_{\mathrm{i}}+2.12-0.344 \mathrm{q}_{\mathrm{i}}+0.061 \mathrm{q}_{\mathrm{i}}^{2}$ & (أقل من فدان) & 11 \\
\hline $\mathrm{ATc}_{\mathrm{i}}=5.01 / \mathrm{q}_{\mathrm{i}}+1.21-0.316 \mathrm{q}_{\mathrm{i}}+0.072 \mathrm{q}_{\mathrm{i}}^{2}$ & ألفئة الثانية & 12 \\
\hline $\mathrm{ATc}_{\mathrm{i}}=3.46 / \mathrm{q}_{\mathrm{i}}+2.52-0.779 \mathrm{q}_{\mathrm{i}}+0.121 \mathrm{q}_{\mathrm{i}}^{2}$ & (2فئة الثالثة & 13 \\
\hline
\end{tabular}

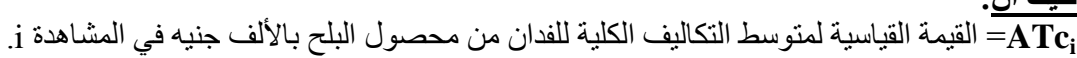

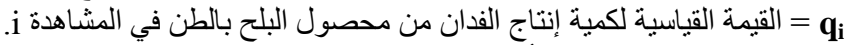

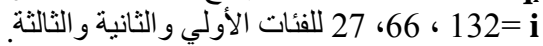
المصدر: جُمعت وحُسبت من المعادلات الواردة بجدول 9. 
2.83

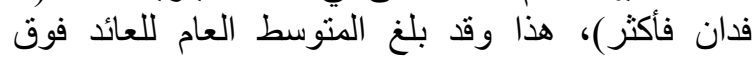

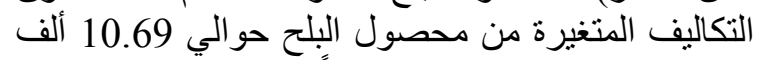
جنيه، بما يو ازي حو الي 2.73 جنيهاً لكل كجم من البع المحصول.

\section{القيمة المضافة}

بلغت القيمة المضافة لمحصول البلح أدنى قيمة له له بله

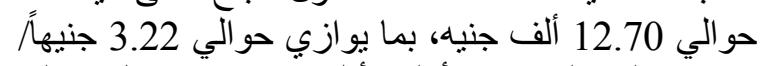
كجم في الفئة الحيازية الأولى (أقل من فدان)، مقابل حولي حوالي

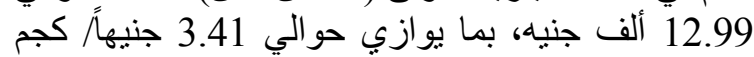

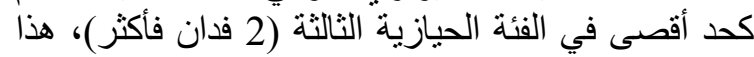

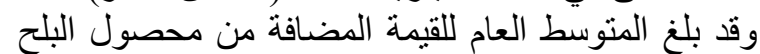
حوالي 12.78 ألف جنيه، بما يوازيمة الفي حون الي 3ن 3.27جنيها

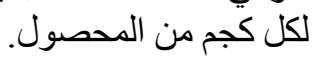

\section{مقاييس الكفاءة الاقتصادية لمحصول البلح بمختلف بلف بلفية الفئات الحيازية بعينة الداراسية:}

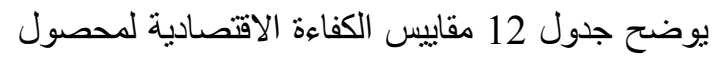
البلح بمختلف الفئات الحيازية بعينة الدراسة في محافظة الافية لئلة

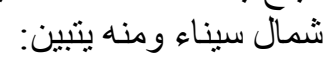

\section{نسبة العائد للتكاليف}

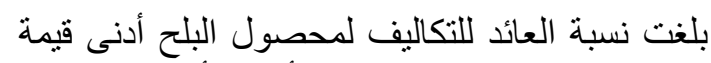

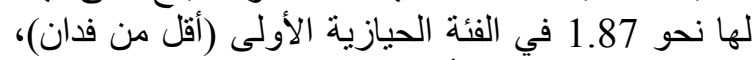

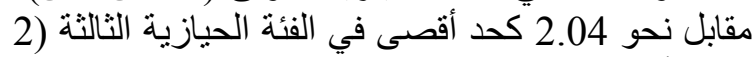
فدان فأكثر)، بمنوسط عام بلغ نحو 1.91.

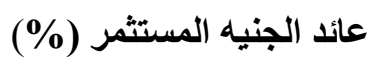

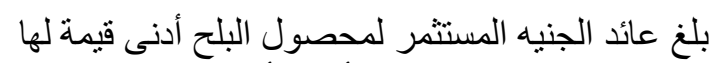
نحو 87.0\% في الفئة الحيازية الأولى (أقل من فدان)، مقابل الفيل 2 نحو 103.8\% كحد أقصى في الفئة الحيازية الثالثنة فدان فأكثر)، بمنوسط عام بلغ نحو

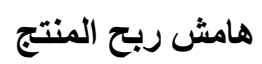

بلغ هامش ربح المنتج لمحصول البلح أدنى قيمة لها

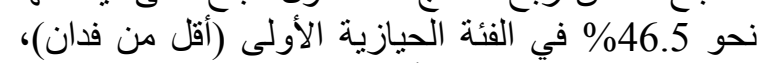
مقابل نحو 50.9\% كحد 5 أقصى في الفئة الحيازية الثالثة

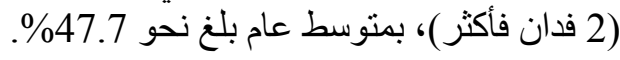

$$
\text { الربحية النسبية }
$$

بلغت الربحية النسبية لمحصول البلح أدنى قيمة لهابه

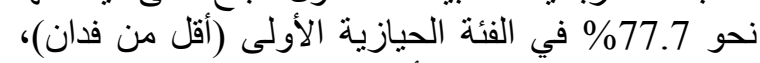
مقابل نحو 81.0\% كحد أقصى في الفئة الحيازية الثالثة (2 فدان فأكثر )، بمتوسط عام بلغ نحو 18.6\%

\section{الكفاءة الاقتصادية}

بلغت الكفاءة الاقتصادية لمحصول البلح أدنى قيمة لها لهايه

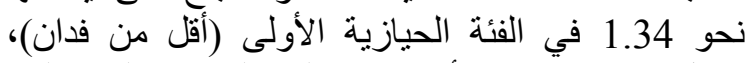

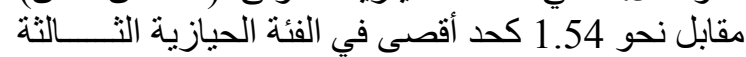

وتثبير القياسات المتحصل عليها أن معامل التحديد

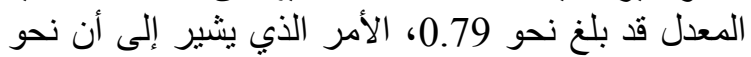

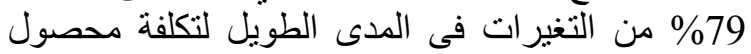

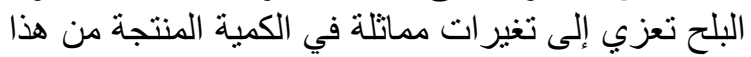

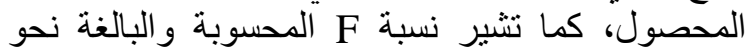
142.6 إلى مدى مطابقة النموذج المئن المستخدم لطبيعة

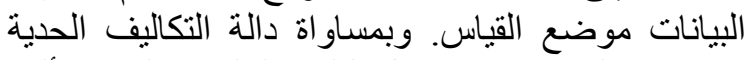

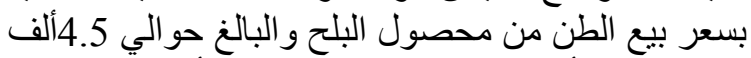

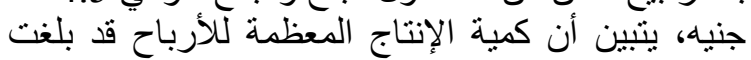

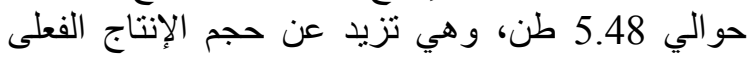

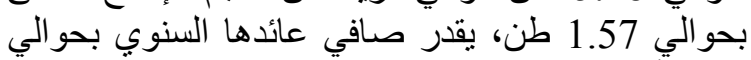
3.38 ألف جنيه.

وبايجاد المشتقة الأولى لدالة متوسط التكاليف الكلية

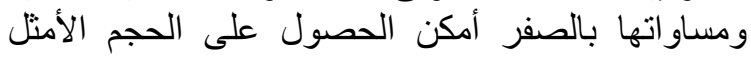

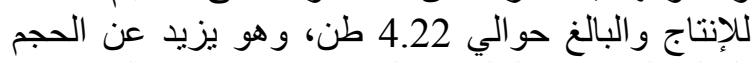

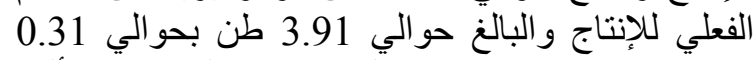

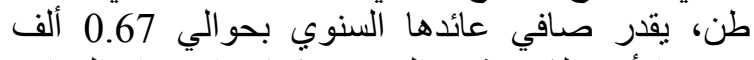

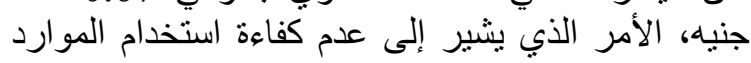

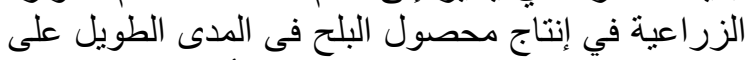

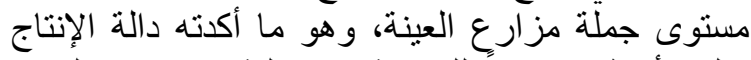

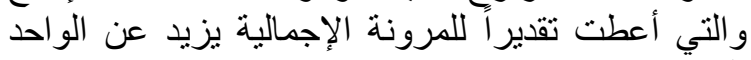

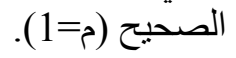

الهوامش الربحية ومقاييس الكفاءة الاقتصادية لمحصول البلح بعينة الاراسة في محافظة شمالّ الهيازية بعينة الأراسة لمصول البلح بمختلف الفئات

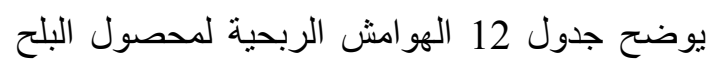
بمختلف الفئات الحيازية بعينة الدراسة بمحافظة الربة شمال سيناء ومنه يتبين أن: صافي العائد بلغ صافي العائد لمحصول البلح أدنى قيمة له حوالي الي الي

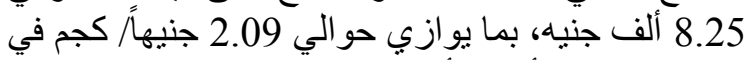

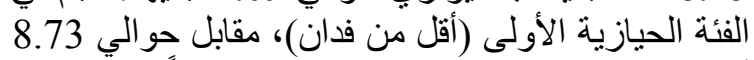

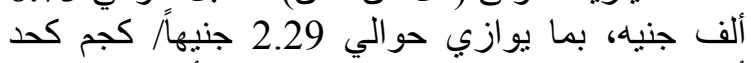

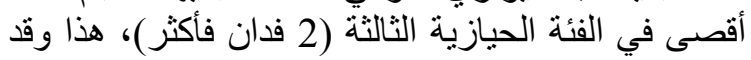

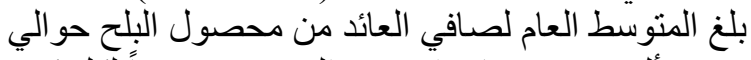
8.40 ألف جنيه، بما يو أزي حو الي 2.15 جنيهاً لكل كجم من المحصول.

\section{العائد فوق التكاليف المتغيرة}

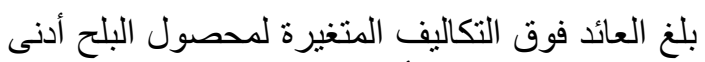

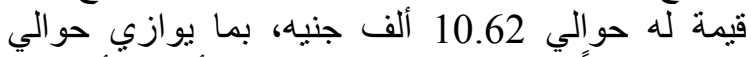
2.69 جنيهاً/كجم في الفئة الحيازية الأولى (أقلى من فدان)، مقابل حو الي 10.78 ألف جنيه، بما بو ازئ الفي حو الي 
جدول 12. الهوامش الربحية ومقاييس الكفاءة الاقتصادية لمحصول البلح بمختلف الفئات الحيازية بعينة الدراسة في محافظة شمال سيناء خلال متوسط عالمى 2018، 2019.

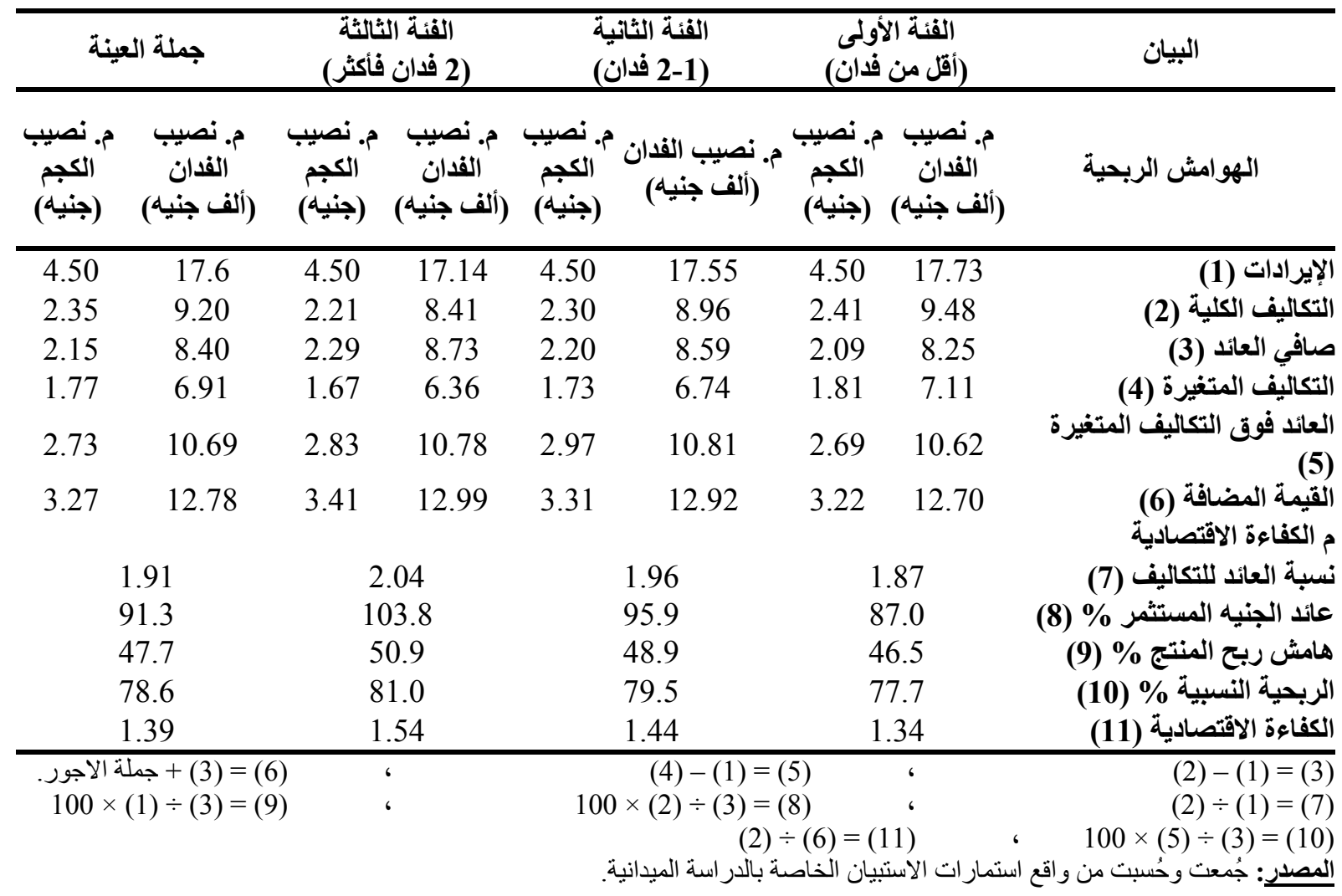

4- الاستفادة المثلى من الكميات المنتجة وذللك خلال

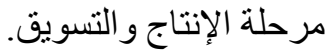

$$
\text { المراجـع }
$$

الصياد، مصطفي. الإحصاء الاجتماعي، عين شمس، القاهرة، صفحة 108 الإن

حسن، فوزية أبو زيد صابر (2011). دراسة اقتهادية

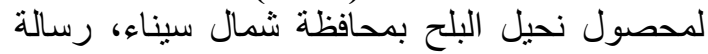

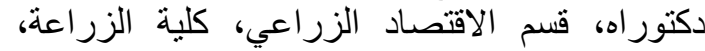
جامعة عين شمس.

مركز المعلومات ودعم اتخاذ القرار (2018).

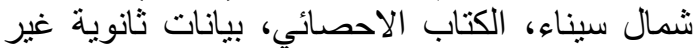

$$
\text { منشورة. - منال }
$$

وزارة الزراعة واستصلاح الاراضي، مديرية الزراعة

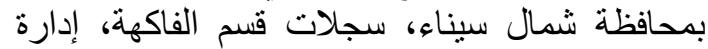
النخيل، بيانات غير منشورة، أعداد متفرقة.
(2 فدان فأكثر)، بمتوسط عام بلغ نحو 1.39، مما يشير

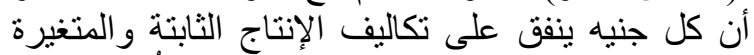

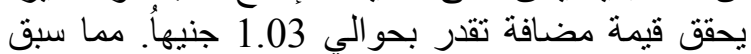

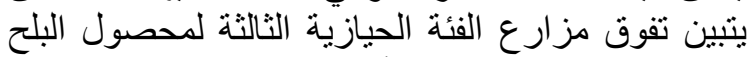

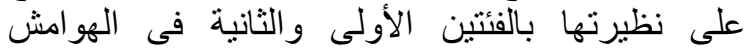
الربحية، وكذللك مؤشرات الكفاءة الاقتصادية. مما يثير الثير

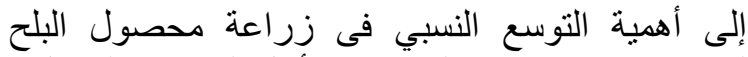
للاستفادة من وفورات السعة فى الأجل القصير و الطويل.

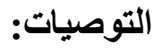

1- ضرورة زيادة المساحة المزروعة من البرة البلح نظراً لتوفر الظروف من مساحات كبيرة بالأضافة الطية إلى نئ طبيعة البيئة المناخية المناسبة. 2- أهمية التوسع النسبة فى زر اعة محصول نخيل البلح للإستفادة من وفرات السعة في الألى السل القصبير

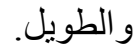

3- إتباع برنامج المكافحة المتكاملة ضد الحشرات وخاصة (سوسة النخيل). 


\section{المُلخص العربي

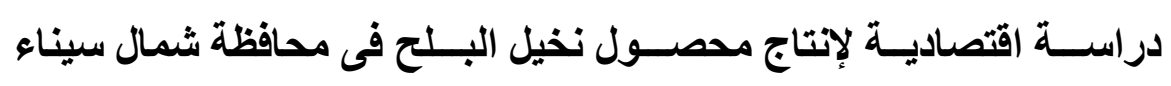 \\ حسام الدين يوسف طفيلي *1، سعاد عبدالفتاح إبراهيم، رجب محمد حفني1 1 \\ 1. قسم الاقتصاد و التتمية الريفية، كلية العلوم الزر اعية البيئية، جامعة العريش، مصر.}

تعتبر أشجار نخيل البلح ومنتجاتها المتماثلة كمنتج ثانوي من أهم الزراعات فى المناطق الجديدة والصحر اوية،

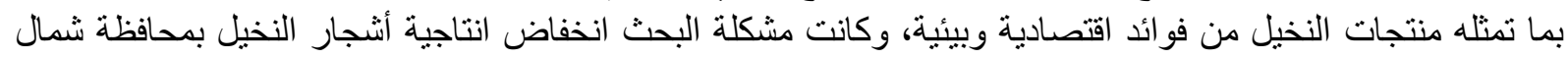

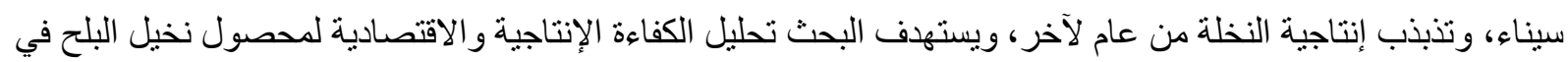

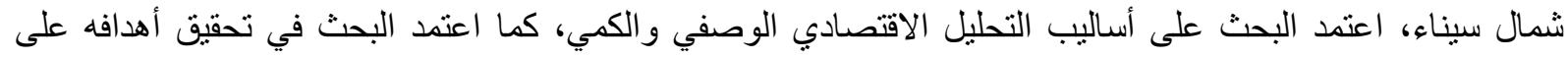

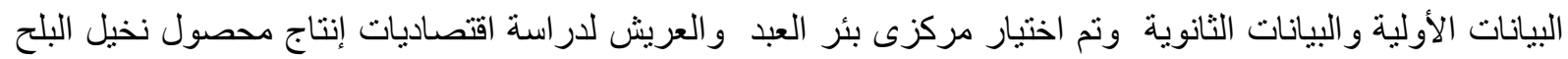

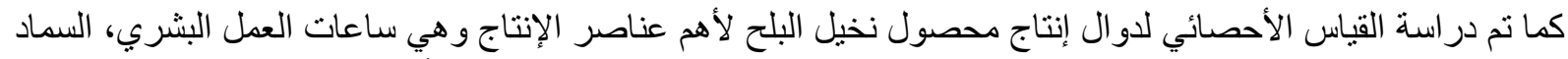

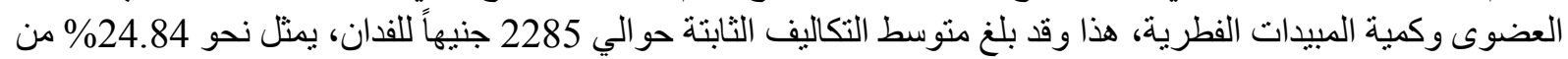

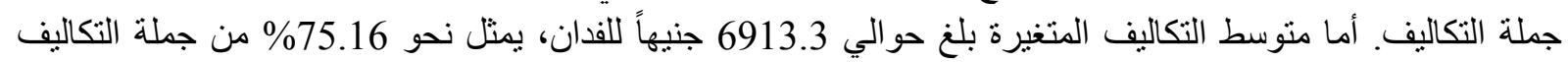

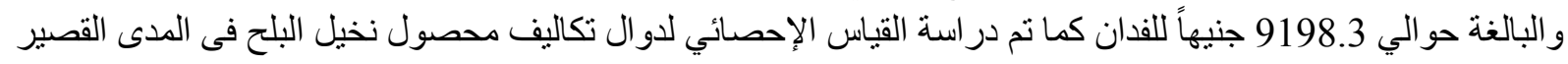

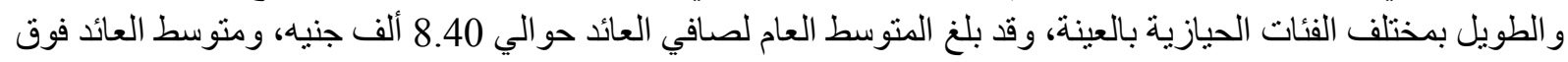

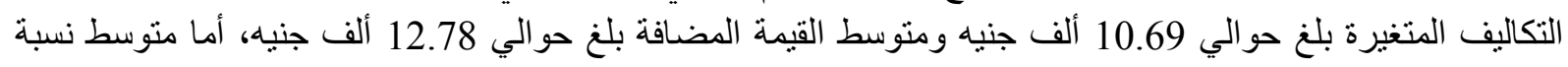

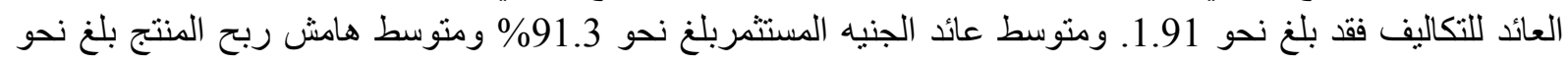

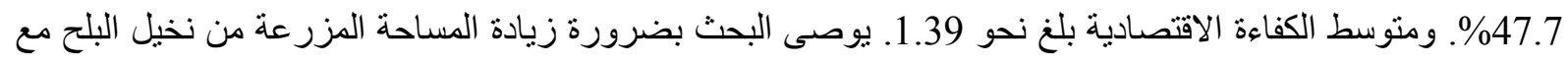
المحافظة عليه من الحشر ات (سوسة النخيل) و الاستفادة المتلى عند التسويق من الكميات الإنتاجية.

الكلمات الإسترشادية: نخيل البلح، التكاليف، الإنتاج، محافظة شمال سيناء.

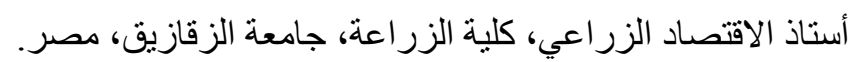
أستاذ الاقتصاد الزراعي، كلية العلوم الزر اعية البيئية، جامعة العريش، الزية، مصر.

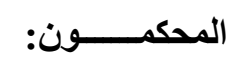

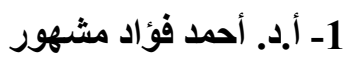

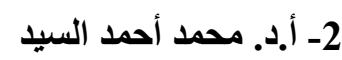

